\title{
Geleneksel Mimariye Öykünme Bağlamında Günümüz Safranbolu Sivil Mimarisi
}

\author{
BÜLENT ORAL \\ bulentoral7@gmail.com \\ ORCID ID: 0000-0003-1247-4679
}

Öz: Bu çalışmada Safranbolu geleneksel mimari üslubunun günümüzde inşa edilmiş yapılara etkisini örnek yapılar eşliğinde ortaya koymak amaçlanmıştır. Böylece konu edilen çalışma bağlamında günümüz sanat yaklaşımlarını etkileyen unsurlar, bu unsurları ortaya çıkaran etkenler ile tüm bunların modern sanata etkisi açıklanmıştır. Kentte geleneksel dokuya öykünme özellikle Eski Çarşı, Kıranköy ve Bağlarbaşı Mahallesine yakın ya da o bölgeye hâkim noktalarda yer alan mahallelerde yoğunlaşmış olup bu yöndeki eğilimin artarak devam ettiği görülmektedir. Tarihi Safranbolu kentinin ülkemiz sinırları içinde UNESCO tarafindan Dünya Kültür Mirası olarak kabul edilen tek kentsel sit alanı olması Safranbolu'nun modern yapı uygulamalarında geleneksel yapıya öykünme ya da onu temsil edebilecek uygulamalar ile modern ve geleneksel mimari arasında uyum yakalama çabalarını görünür kılmıştır. Özellikle 2000 yil ve sonrasında yeni inşa edilen siteler ve konaklama tesislerindeki geleneksel dokuya öykünme çabaları, modern dönemde inşa edilmiş binalarda geleneksel ögelerin mimariye seçmeci anlayışta taşındığı yapı tiplerini ortaya çıkarmıştır.

Anahtar kelimeler: Safranbolu, Mimari, Modern, Geleneksel, Sivil.

\section{Giriş}

Sanat tarihinde geçmişe öykünme çabası dönemin sosyal ve siyasal gelişmeleri ile paralellik gösteren sanat anlayışlarından kaynaklanmıştır. Örneğin Batı Sanatı Neoklasik Dönemi’nde Antik Çağ ve Rönesans’a çizgisel üslup ve anlayışla bağlı yapıtlar ortaya konulmuştur. Türk Sanatı́nda da geçmişe öykünme ile geçmişe ait özgün çizgisel unsurları yeni dönemin yapıtlarında uygulama örnekleriyle karşılaşmaktayız. Örneğin I. ve II. Ulusal Mimarlık Dönemleri’nde geçmiş dönemin sanatsal yaklaşımlarını yeniden uygulama çabaları görülür. I. ve II. Ulusal Mimari Dönemleri’nde ortaya çıkan yapılarda Selçuklu ve Osmanlı Dönemi mimari ve süsleme detayları seçmeci anlayışta yapının iç ve dış mimarisine taşınmıştır. Safranbolu'da inşa edi-

* Dr. Öğr. Üyesi, Karabük Üniversitesi, Edebiyat Fakültesi, Sanat Tarihi Bölümü. 
len farklı türdeki yapıların bir kısmında geleneksel Safranbolu mimarisine öykünme gözlemlenmektedir ancak burada ortaya çıkan durum Neoklasik Dönem ile I. ve II. Ulusal Mimarlık Dönemleri'nde ortaya çıkan gelişmelerle yer yer paralellik gösterse de yapıların birçoğunda geleneksel mimariye öykünmenin başkaca nedenlere dayandığı da görülmektedir.

18. yüzyıldan itibaren arkeoloji ve sanat tarihi alanlarının gelişmesi ile birlikte eski uygarlıklara ait kalıntıların birer kültür varlığı olarak tespit edilmesi ve korunması öncelenmiş, böylece tarihi kentlerin yer yer korunması sağlanmıştır. 20. yüzyıldan itibaren Avrupa'da kültür varlıklarına gösterilen önem giderek artmış, ülkemizde de buna paralel olarak hem kamusal alanda hem de sivil alanda önemli çalışmalar yapılmıştır. Böylece çeşitli bölgelerdeki kültür varlıklarının ortaya çıkarılması, restore edilmesi ve muhafaza edilmesi hususundaki hassasiyet giderek artmıştır.

Aktüre ve Şenyapılı, koruma kararlarının ilk kez alındığı yıllarda yayınladıkları "Safranbolu’da Mekânsal Yapının Gösterdiği Nitelikler” başlıklı makalelerinde Safranbolu Eski Çarşı (Çukur) ve Bağlar mahallelerinde yaşayan insanların tarihi dokunun korunması hususundaki görüşleri hakkında şunu söylemektedirler.

Doğal ve tarihi yerleri koruma bilincinin, çoğunlukla bu bilinci geliştireceğini umduğumuz yoksul yerel topluluk açısından "lüks" olarak değerlendirildiği veya temel sorun olan "geçim" uğruna kolaylıkla vazgeçilebilir görüldüğü izlenir. Bu nitelikteki toplumlarda koruma sorunlarının gelirleri geçim düzeyinin çok üstünde olan gruplarca ortaya atılmasının tesadüf olmadığı, arkasında kent soylu romantizmi ya da spekülasyon umutları yattığı bugün öne sürülen bir görüştür. Safranbolu’da böyle bir bilincin doğmamış olması olağandır; bunun oluşması gerçekte çok farklı şartları gerektirirdi. ${ }^{1}$

Aktüre ve Şenyapılı’nın bahsettiği, özellikle 1995 yılında Safranbolu’nun Uluslararası düzeyde koruma altına alınmasının ortaya çıkardığı sonuçlar 2000'li yıllarda karşılık bulmuştur.

Safranbolu imar planının günümüze değin belirli aralıklarla yeniden çizildiği görülmektedir.

Safranbolu'nun ilk imar planı 1936 yılında tasarlanmıştır. Bu erken tarihli imar planında günümüzde Emek Mahallesi olarak bilinen yer büyüme alanı olarak belirlenmiştir. Burada çeşitli tipolojilerde işçi konutları inşa edilmiştir. Yanı başındaki Karabük'te kurulacak olan Demir-Çelik Fabrikası'nın yeni konut ihtiyacı doğurabileceği ihtimali ile tarihi merkezler çevresindeki boş alanlar imara açılmıştır. 1936 tarihli imar planının ardından 1968 yılında yapılan bir yarışma ile önerilen imar planında tarihi dokunun korunması gerektiği vurgusu olumlu bir hava yaratmıştır. ${ }^{2}$

1 Sevgi Aktüre, Tansı Şenyapılı, Safranbolu’da Mekânsal Yapının Gösterdiği Nitelikler, O.D.T.Ü. Mimarlık Fakültesi Dergisi, 2/I (1976), s.92.

2 Rüveyda Yetiş, Yüksel Turcan ve Ahmet Emre Dinçer, Safranbolu Kent Formunun Tarihsel Serüveni ve Morfolojik İncelemesi, "DeğişKent” Değişen Kent, Mekân ve Biçim Türkiye Kentsel Morfoloji Araştırma Ağı II. Kentsel Morfoloji Sempozyumu, İstanbul: 2018, s.495-505. 
Özellikle 1994 yılında Safranbolu’nun UNESCO Dünya Kültür Mirası Listesi’ne dahil edilmesi, kent için yeni bir süreç doğurmuştur. Bu karar sonucu Osmanlı Devleti döneminde yerleşim merkezi olan ve günümüzde Eski Çarşı olarak adlandırılan tarihi Safranbolu şehri koruma kapsamına alınmıştır. Kamu kurumlarının bu karar öncesinde başlattıkları tarihi kent dokusu özelliği gösteren yapıların tespiti, yerleşim alanlarının koruma altına alınması ve sit alanı ilan edilmesi yönündeki çalışmalar UNESCO'nun aldığı kararı kolaylaştırmıştır. UNESCO'nun aldığı karar kente yerli ve yabancı turistlerin ilgisini artırmış, ortaya çıkan ekonomik getiri ile restorasyon, konservasyon veya konsolidasyon, renovasyon ve rekonstrüksiyon çalışmaları artmış böylece kent özgün mimari dokusunu büyük oranda koruyabilmiştir. Bu gelişmeler hem sit alanı içinde hem de yeni kent dokusunun geliştiği bölgelerde inşa edilen yapıların bir kısmını mimari açıdan da etkilemiştir.

Koruma kararları öncesi ve koruma kararlarının uygulandığı ilk örneklere dönük eleştiriler içeren yayınlar da yapılmıştır. Hacısalihoğlu UNESCO'nun tarihi Safranbolu kenti ile ilgili aldı̆̆ı kararın hemen ertesinde yayınlanan "Geleneksel Türk Şehri: Safranbolu” başlıklı makalesinde tarihi yerleşim yeri olan Eski Çarşı'nın fonksiyonel çeşitliliğini kaybettiğini, eski canlılığını sürdürememesi buna karşın koruma kararlarına bağlı olarak şehre yeni, uygulanabilir, realist bir fonksiyonlaşma kazandırılamamasının bir sonucu olarak yeni gelişen yerleşim alanlarıyla olan sosyal, kültürel ve iktisadi farklılığın giderek bir problem haline dönüştüğünü belirtir ${ }^{3}$. Tarihi kent ile ilgili alınan kararların henüz ortaya çıkmaya başladığı bu dönem kentin tarihi kimliğini günümüze taşıyacak gelişmelerin habercisi olmuştur.

Safranbolu'da Osmanlı kent dokusuna sahip Eski Çarşı (Çukur) olarak adlandırılan bölge önemli bir yerleşim yeri olma vasfını günümüzde de sürdürmektedir. Eski Çarşı'ya ek olarak Kıranköy, Bağlarbaşı (Ötebağlar-Bağlar), Aşağıtokatlı gibi bölgelerde de tarihi kent dokusuna sahip yerleşim yerleri vardır. Bu mahalleler arasında kalan bölgeler 20. yüzyıl boyunca çeşitli dönemlerde hızlanan yapılaşmaya bağlı olarak genişleyerek yeni bir şehir dokusu ortaya çıkarmıştır.

$\mathrm{Bu}$ mimari yapılar çoğunlukla modern mimari malzemelerle inşa edilen ve belirli bir mimari döneme atıf içermeyen işlevsel yapılardır. Nartkaya ve Tektaş’ın "Erken Cumhuriyet Dönemi Safranbolu Konut Yapılarında Kimlik Arayışı” başlıklı bildiri metninde Safranbolu'nun Erken Cumhuriyet Dönemi'nde yapılan bazı yapılarının belirli sanatsal üsluba dayanan modern mimarlık anlayışı ile inşa edilmiş olabileceği belirtilmiştir ${ }^{4}$. Ancak bildiri metninde, verilen örneklerin sayıca az olması ayrıca metne konu edilen yapıların plan ve cephe özelliklerinin belirli bir mimari üsluba bağlı kalma amacıyla gerçekleştirildiğini gösteren çizgi ve üsluba yeterli oranda sahip olmadığı da görülmektedir. Erken Cumhuriyet Dönemi’nde ortaya çıkan yeni kent dokusu çoğunlukla betonarme tek ya da çok katlı binalar şeklinde oluşturul-

3 İlhan Yaşar Hacısalihoğlu, Geleneksel Türk Şehri: Safranbolu, Safranbolu: Türk Coğrafya Dergisi, XXX (1995), s.433.

4 Esra Nartkaya, Elif Tektaş, Erken Cumhuriyet Dönemi Safranbolu Konut Yapılarında Kimlik Arayışı, Dicle Üniversitesi I. Uluslararası Mimarlı Sempozyumu (Dicle University I. International Architecture Symposium), 2018. 
muştur. Bununla birlikte kentin UNESCO Dünya Kültür Mirası Listesi’ne dahil edilmesinden sonra inşa edilen yapılarda geleneksel mimariye öykünme yoğunlaşmıştır.

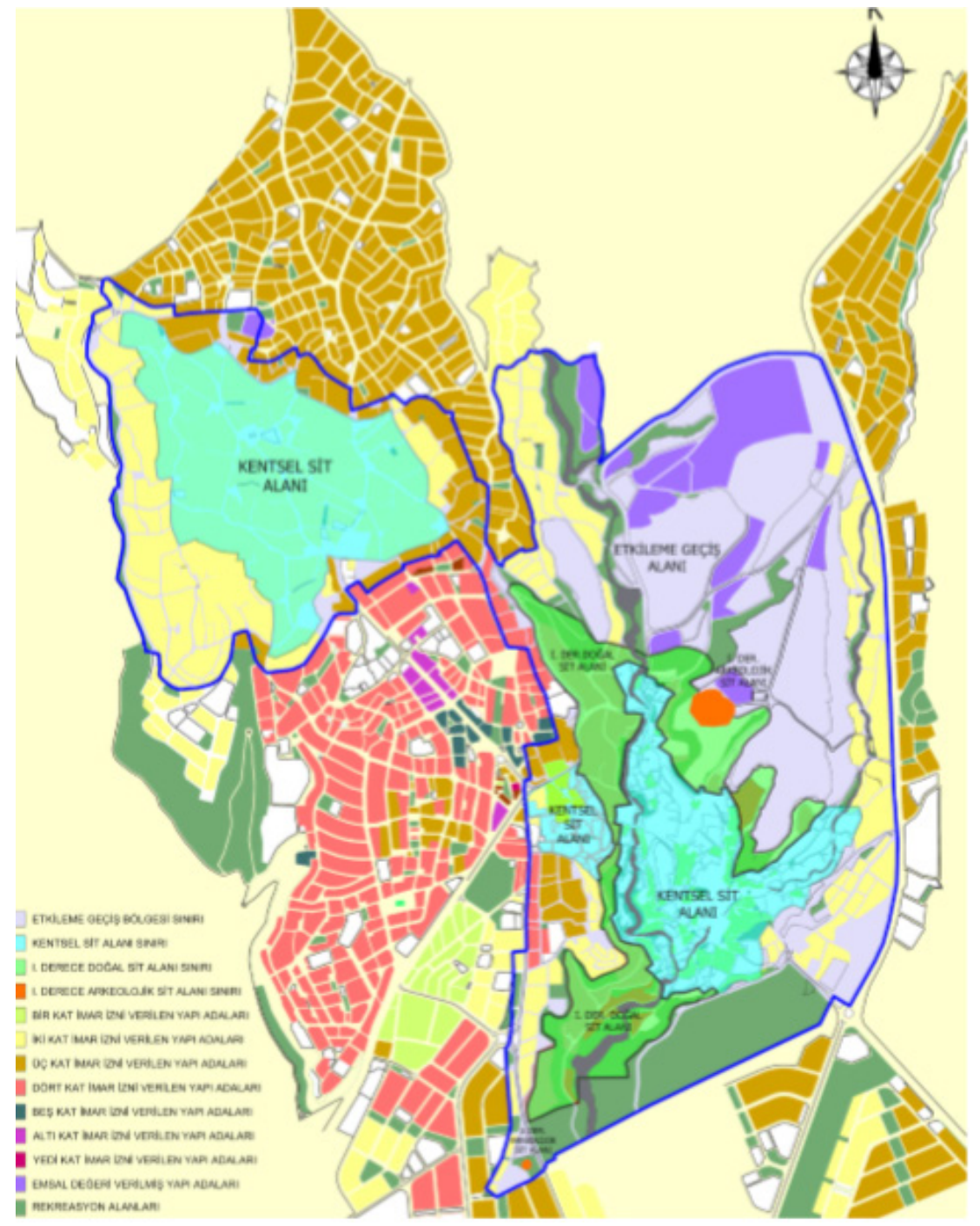

Şekil 1. 2010 yılı Koruma Amaçlı İlave + Revizyon Uygulama İmar Planı İmar Planı ${ }^{5}$

Bu çalışmada Safranbolu geleneksel mimari üslubunun günümüzde inşa edilmiş yapılara etkisini örnek yapılar eşliğinde ortaya koymak amaçlanmıştır. Böylece günümüz sanat yaklaşımlarını etkileyen unsurlar, bu unsurları ortaya çıkaran etkenler ile tüm bunların modern sanata etkisi açıklanmıştır.

Safranbolu'da özellikle 20. yüzyılın son çeyreğinden itibaren nicel olarak daha görünür olan, tarihi kent dokusunun mimari üslup ve karakterine sahip modern yapılar dikkat çekmektedir. Geleneksel mimari özellikleri taşıyan modern yapılar turistlere

5 Anonim, (Abad Proje Proje Yapı Turizm Sağlık Enerji San. ve Tic. A.Ş.) Safranbolu (Karabük) (Korumanın Başkenti) Koruma Amaçlı Revizyon + İlave Nazım ve Uygulama İmar Planı Araştırma Raporu'nun revize edilerek birleştirilmiş kent imar planı 2010. Revize eden ve aktaran: Rüveyda Yetiş, Yüksel Turcan ve Ahmet Emre Dinçer, Safranbolu Kent Formunun Tarihsel Serüveni ve Morfolojik İncelemesi, "DeğişKent” Değişen Kent, Mekân ve Biçim Türkiye Kentsel Morfoloji Araştırma Ağı II. Kentsel Morfoloji Sempozyumu, İstanbul: 2018, s.512. 
hitap eden çeşitli ticari nitelikli binalarda yoğunlaşmaktadır. Geleneksel Safranbolu mimarisinden etkilenen modern sivil mimari yapıları; konutlar, kamu binaları ile özerk-yarı özerk kuruluşlara ait yapılar, ticari yapılar ve meydanlardaki peyzaj düzenlemeleri şeklinde sınıflandırmak mümkündür.

\section{Safranbolu'nun Kısa Tarihçesi}

Paleolitik Çağ’dan itibaren çeşitli medeniyetlere barınak olan Safranbolu, su kaynaklarına ve verimli arazilere sahip bir vadinin yamacına kurulmuştur. Günümüzde de önemli bir yerleşim yeri olan şehir; Hititlerden Roma'ya, Bizans'tan Osmanlı’ya değin birçok medeniyete ev sahipliği yapmıştır. Safranbolu hakkındaki bilinen ilk yazılı kaynaklar Roma İmparatorluk Dönemi’ne aittir.

Konu hakkında batılı kaynakların farklı görüşler ileri sürdüğü belirtilmekle beraber ${ }^{6}$ Bizans döneminde Dadybra olarak adlandırıldığı anlaşılmaktadır ${ }^{7}$ Bölge, 1100 yılında Danişmentoğulları’nın eline geçerek ilk kez Türk kültürü ile tanışmıştır. Safranbolu 13. yüzyılda Çobanoğulları'nın, 14. yüzyılda ise Candaroğulları'nın hâkimiyeti altına girmiştir ${ }^{8} .1392$ yılında Osmanlı Devleti’nin Candaroğulları ile yaptıkları savaş sonucunda bölge Osmanlı Devleti’ne geçmiştir ${ }^{9}$. Kentin Osmanlı kültürü ile yoğrulması sürecinde adı Zalifre olmuştur. Sonra sırasıyla Borlu, Taraklıborlu, 18. yüzyılda Zağfiran-1 Bolu, 19. yüzyılda Zağfiranbolu, Cumhuriyet döneminde ise Safranbolu olarak adlandırılmıştır. Kent, 1927 yılında Zonguldak iline, 1955 yılında ise Karabük iline bağlı ilçe statüsüne alınmıştır. ${ }^{10}$ Şehir Merkezi (Eski Çarşı), Akçasu ve Gümüş derelerinin birleştiği üçgen içindedir. ${ }^{11}$

Kent ilk kez Kültür ve Turizm Bakanlığ 1 Gayrimenkul Eski Eserler ve Anıtlar Yüksek Kurulu'nun 8 Ekim 1976 yılında aldığı karar ile koruma altına alınmıştır ${ }^{12}$. 2 Mayıs 1985 tarihinde Bağlar ve Çarşı bölgelerinde yer alan kentsel sit alanı ve doğal sit sınırlarındaki 810 sivil mimari yapı ile 165 anıt eser Taşınmaz Kültür Varlıkları Yüksek Kurulu tarafindan tescil edilmiştir. ${ }^{13}$ Kentin Koruma amaçlı imar planı da 1991 yılında kabul edilmiş ve nihayetinde kent 1994 yılında UNESCO tarafından Dünya Kültür Mirası Listesi'ne alınmıştır. ${ }^{14}$

6 Erdoğan Merçil, Selçuklular Devrinde Karadeniz ve Safranbolu, (I. Ulusal Tarih İçinde Safranbolu Sempozyumu 4-6 Mayıs 1999), Karabük: Türk Tarih Kurumu Basımevi, 2003, s.2.

7 Ahmet Gökoğlu, Paphlagonia-Paflagonia, Kastamonu, Sinop, Çankırı, Safranbolu, Bartın, Bolu, Gerede, Mudurnu, İskilip, Bafra, Alaçam ve Civarı Gayrimenkul Eski Eserleri ve Arkeolojisi. Kastamonu: Doğrusöz Matbaas1, I, 1952, s.33.

8 Arşiv Belgelerinde Karabük, haz., Recep Karacakaya, İsmail Yücedağ, Nazım Yılmaz, İstanbul: Safranbolu Belediyesi Kültür Yayınları, 2013, s.18,19.

9 Safranbolu Şer'iyye Sicili, 2116 Numaralı Defter, haz., Recep Karacakaya, İsmail Yücedağ, Nazım Yılmaz, İstanbul: Safranbolu Belediyesi Kültür Yayınları 2013, s.30.

10 Türkiye’nin Dünya Miras Alanlar, Koruma ve Yönetimde Güncel Durum, UNESCO Türkiye Milli Komisyonu Somut Kültürel Miras İhtisas Komitesi, haz., Ayşe Bayvas, Ankara: UNESCO, 2009, s. 222.

11 Reha Günay, Türk Ev Geleneği ve Safranbolu Evleri, İstanbul: YEM, 1998, s.113.

12 Nigan Bayazıt, Safranbolu Geleneksel Konutları ve Toplumsal Değişme, İstanbul: Safranbolu Belediyesi Safranbolu Araştırmalar Merkezi Kültür Yayını, 2014, s.15.

13 Türkiye’nin Dünya Miras Alanları, UNESCO, s.230.

14 Türkiye’nin Dünya Miras Alanları, UNESCO, s.230. 


\section{Tarihi Safranbolu Evlerinin Genel Özellikleri}

Anadolu'nun batısından Balkanlar'a kadar yayılan bir alanda takip edebildiğimiz ev biçimi Safranbolu'da da görülür. ${ }^{15}$

Safranbolu, Kastamonu, Sinop ve Amasya'daki evler Kuzey Anadolu evleri olarak gruplandırılmıştır. Kuzey Anadolu evleri ormanlık ve nispeten bol yağışlı bir bölgenin ürünüdür. Ev planları geç bir devre kadar (18. yüzyıl) açık sofalarını korumuştur. Daha sonraki gelişimi ise iç ve orta sofa yönünde şekillenmiştir. ${ }^{16}$ Evlerin ana taşıyıcı sistemi taş üzerine ahşap çatkı arası çoğunlukla kerpiç, seyrek olarak da küçük taşlarla doldurulmuştur. ${ }^{17}$ Evlerin duvarlarında ahşap malzemenin kullanıldığı dört farklı sistem bulunur. Bunlar; kerpiç, ahşap, taş ve taş-kerpiç dolma duvarlardır. ${ }^{18}$ Evlerin zemin katları taştandır ve topografyaya uyarak üst katlara temel oluşturur. Üst katlar ahşap çatkılıdır. Var ise orta kat alçak tavanlı ve az sayıda pencereye yer verilmiştir. Üst katta ise çok sayıda pencereye yer verilmiş ve çıkmalarla hareketlendirilmiştir. ${ }^{19}$

Tarihi Safranbolu kentinde 2000'e yakın geleneksel ev ve konak bulunmaktadır. ${ }^{20} \mathrm{Ki}$ tabesi günümüze ulaşan 67 Safranbolu evi arasında en erken yapı 1786 yılına, en geç inşa edilen yapı ise 1929 yılına aittir. ${ }^{21}$ Bağlarbaşı Mahallesi’nde az sayıda dış sofalı planın uygulandığı görülmekte ${ }^{22}$ yaygın olarak iç ve orta sofalı plan tipleri göze çarpmaktadır. Evler genellikle zemin üzerine 2 katlıdır. Sofanın konumlandırıldığı yer ve biçimi sofayı çevreleyen oda ve birimlerin konumunu etkilemiştir. Odaların boyutları kullanılma amacına bağlı olarak değişiklik göstermektedir.

Safranbolu evlerini konumlandırıldığı yerin sokak boyunca uzanan beden duvarları ve bahçe duvarları sınırlamıştır. Evler taş temel üzerine penceresiz olarak inşa edilmiştir. ${ }^{23}$ Üst kat odaların tavan yükseltisi orta kata nazaran daha yüksek, ${ }^{24}$ orta kat yükseklikleri üst kata nazaran dar ve pencereleri de daha küçük tutulmuştur. ${ }^{25}$ Oda, evde yaşamın sürdürüldüğü en önemli birimdir. Odayı sırasıyla mutfak, sofa, hayat ve avlu takip eder. Her bir oda işlevsel niteliklere sahiptir ve üstlendiği işleve göre

15 Günay, Türk Ev Geleneği, s.114; Sedat Hakkı Eldem, Türk Evi, Ankara: Türkiye Anıt ve Çevre, Turizm Değerlerini Koruma Vakfi, 1984, s.28.

16 Eldem, Türk Evi, s.58.

17 Aysun Özköse, "Safranbolu’da Yorgun Ahşap Yapı Kültürü”, Ahşap Kültürü Anadolu’nun Ahşap Evleri, haz., Aysun Özköse, Ankara: Kültür Bakanlığı Yayınları, 2001, s.43.

18 Şeref Kara, Burhanettin Uysal ve M. Reşat Sümerkan, “Tarihi Safranbolu Evlerinin İskelet Yapısı”, Ahşap Kültürü Anadolu’nun Ahşap Evleri, haz., Aysun Özköse, Ankara: Kültür Bakanlığı Yayınları, 2001, s.60; Selvinaz Gülçin Bozkurt, 19. yy’da Osmanlı Konut Mimarisinde İç Mekan Kurgusunun Safranbolu Evleri Örneğinde İdelenmesi, Journal of the Faculty of Forestry, Istanbul University, 62/II (2013), s.37-70.

19 Eldem, Türk Evi, s.58; Günay, Türk Ev Geleneği, s.136.

20 Safranbolu'da Kültür ve Medeniyet İzleri Araştırması, haz., Hür Mahmut Yücer, Proje Yöneticisi, Sami Şener, Safranbolu: Safranbolu Belediyesi Kültür Yayınları, 2014, s.39.

21 Recep Karacakaya, İsmail Yücedağ, ve Bülent Nuri Kılavuz, Safranbolu Kitabeleri, İstanbul: Safranbolu Belediyesi Kültür Yayınları, 2013, s.313.

22 Günay, Türk Ev Geleneği, s.59-62.

23 Günay, Türk Ev Geleneği, s.136.

24 Günay, Türk Ev Geleneği, 1998, s.136; Nurhan Koçan, Safranbolu'da Zaman ve Mekân, İstanbul: Safranbolu Belediyesi Kültür Yayınları, 2012, s.180.

25 Reha Günay, Geleneksel Safranbolu Evleri ve Oluşumu, Ankara: Kültür Bakanlığı Yayınları, 1981, s.62. 
adlandırılmıştır. ${ }^{26}$ Örneğin; Baş oda, evin en büyük ve süslemesi yoğun odası olması nedeniyle bu adı almıştır. Diğer bir adı da selamlık olan baş oda, evin erkek misafirleri için ayrılmış olan bölümüdür. Bu oda kolay ulaşılabilmek için merdiven boşluğunun olduğu duvara göre konumlandırılmıştır. ${ }^{27}$ Safranbolu evlerinde sıra odalara pek rastlanmaz. Daha çok köşe odalara rastlanır ve merkezi plan tipi hâkimdir. Safranbolu evleri çevredeki plan tipolojisiyle uyum içindedir. ${ }^{28}$

Duvarların dışı kimi evlerde sıvanmış kimi evlerde ise sıvasız bırakılmıştır. Evlerin çıkmaları ahşap eli böğründeler ve payandalarla desteklenmiştir.

Safranbolu konaklarının iç mekânında sedir, eyvan, seki, dolap, gusülhane, oymalar ve sergenler; evlerin genel özellikleri ve cephelerinde ise, pencereler, kara kapaklar, ev çeşmeleri, kazan ocakları, kapılar, kilitler, sofalar, eyvanlar, oda girişleri, ocaklar ve dolaplar geleneksel yapı unsurlarıdır. ${ }^{29}$

Eski Çarşı (Şehir) Türk dokusunun yoğun olduğu, batıdaki yüksek düzlük ise Rum azınlığın yoğunlukta yaşadığ me Türk evlerine nazaran daha yoğun kullanılmış ve bunun sonucunda da taş oymacılığ Rum evlerinde daha fazla uygulanmıştır. ${ }^{30}$

\section{Geleneksel Mimariye O̊ykünülerek Yaptırılan Konutlar}

Ailelerin gündelik yaşamlarını sürdürdüğü geleneksel etkide yaptırılan konut tipleri üç alt başlıkta incelenmiştir. Bunlar; Çok Katlı Siteler, Villa Tipi Siteler ve Bağımsız Konak, Apartman ile Villalardir.

\section{Geleneksel Etkide Yaptırılan Çok Katlı Siteler}

Modernleşme sürecinin insan yaşamında yarattığı değişimin mimarideki önemli göstergelerinden biri çok katlı betonarme yapılardır. Zamanla bunlar, site sakinlerinin oturduğu etrafı güvenlik amacıyla çevrelenmiş çok katlı binalar, plazalar, alışveriş merkezleri, havuz, spor alanları, oyun parkları, otoparklar, okul ve dini yapılardan oluşan çeşitli kültürel ve özel alanlara da sahip fonksiyonel yapılara dönüşmüştür. $\mathrm{Bu}$ yerleşim şekli belirli bir ekonomik güce sahip insanların güvenlik kaygılarıyla sıklıkla tercih ettiği bir yaşam alanı sunmaktadır. Safranbolu sitelerindeki yaşam, ilçe statüsündeki herhangi bir kentin demografisi ve yaşam anlayışı ile paralellik gösterir.

Turistik açıdan önemli gelir kaynağı olan tarihi Safranbolu, ulusal ve uluslararası düzeyde kentin tanınır olmasını da sağlamıştır. Bu durumun yansıması olarak mimari proje yapan bazı şirketler, modern çok katlı bina inşalarında geleneksel Safranbolu mimarisine atıfta bulunmayı bir pazarlama yöntemine dönüştürmüş böylece alıcılara hitap etmeyi amaçlamışlardır. Safranbolu'daki modern siteler kentin fiziki

26 Reha Günay, Safranbolu Houses, İstanbul: YEM, 2005, s.94.

27 Günay, Safranbolu, s.49.

28 Nigan Bayazıt, "Safranbolu Evlerinin Plan Tipolojisi ve Kullanıcı İhtiyaçları Hiyerarşisi”, Tasarım-Kuram, XIV (2014), s.4.

29 Nigan Bayazıt, Safranbolu Geleneksel Konutları ve Toplumsal Değişme, İstanbul: Belediyesi Safranbolu Araştırmalar Merkezi, Kültür Yayını, 2014, s.14.

30 Günay, Türk Ev Geleneği, s.114 
ve coğrafi koşullarına uygun şekilde konumlandırılmışlardır. Bu siteler içerisinde nicel olarak az olsa da geleneksel Safranbolu konut mimarisinin yansımaları görülmektedir. Geleneksel mimari özelliklerden esinlenen çok katlı binalardan oluşmuş dikkat çeken dört site şunlardır; Barış Mahallesi’ndeki Göztepe Sitesi (1999-2005), Şehirkent Sitesi (2005) ve Ermersa Sitesi (2006) ile Cemalcaymaz Mahallesìndeki Çimkent Sitesi (2002-2004).

Göztepe Sitesi, aynı plan ve cephe özelliklerine sahip dört katlı inşa edilmiş toplam sekiz bloktan oluşmaktadır. Yapılar beton, demir ve ahşap malzemeler kullanılarak çağımızın mimari gelişmelerine uygun inşa edilmiştir. Blokların tamamı dört katlı inşa edilmiş olup, her katta iki daire vardır. Göztepe Sitesi’nde geleneksel Safranbolu mimari özellikleri, blokların cephelerinde belirgin bir şekilde görülmektedir. Sekiz basamaklı merdivenlerle ulaşılan yapıların ön cephelerindeki merdiven boşluğu üç cepheli çıkma şeklinde tasarlanmıştır. Çıkma, geleneksel Safranbolu evlerinde cephenin zemin katından dışa doğru uzanan ve genellikle 3 cepheli cumbaya atıf içermektedir. Katlar boyunca yükselen üç cepheli ve her cephesinde birer pencereye yer verilen çıkma, üstte antik üçgen çatı alınlığı ile geleneksel dokuya uygun bir şekilde tamamlanmıştır. Blokların diğer cephelerinde de geleneksel Safranbolu konutlarında gördügüumüz oda çıkmalarına öykünme söz konusudur. Sitedeki blokların arka cephelerinde ise kapalı balkon düzenlemesi, çıkma odalar görünümündedir. Yan cephelerine bakan odalarda ise çıkma oda özelliği tam olarak görülür. Odalar binanın beden duvarlarından üç cepheli, her cephesinde pencereye yer verilerek dışa taşkın bir şekilde planlanmış ve böylece geleneksel görünüm blokların tüm cephelerinde vurgulanmıştır. Göztepe Sitesi’nin blok cephelerindeki diğer bir geleneksel öykünme ise pencere düzenlemelerinde görülmektedir. Yan yana ikişerli sıralanan dikdörtgen pencereler geleneksel Safranbolu evlerinin en dikkat çekici özelliklerindendir. Pencereler ayrıca geleneksel dokuya uygun olarak ahşap söveli, dekoratif kemer görünümlü ve korkulukludur.

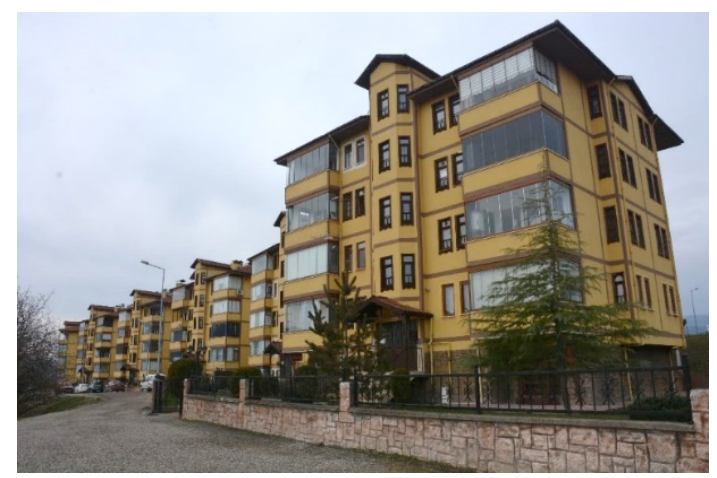

Fotoğraf 1. Göztepe Sitesi Genel Görünüş (kişisel arşiv)

Blokların iç tasarımında geleneksel dokuya bağlılık dış cephelere nazaran yok denecek kadar azdır. Proje, kentin dokusunu dış cephede olabildiğince yansıtabilmek ve böylece geçmiş ile günümüz arasında bir ilişki kurabilmeyi amaçlamış olsa da iç mekân düzenlemesinde kentin geleneksel özelliklerinin yapıya yansıtılması kaygısı duyulmamıştır. Konutlarda iç mekân düzenlemesinin geleneksel dokuya uyarlanma- 
sı hem ekonomik olarak oldukça maliyetlidir hem de geleneksel evlerin iç mekân düzenlemelerinde kullanılan dolap nişi, gusülhane gibi bazı bölümler günümüzdeki yaşam alanı ihtiyaçlarından ayrışmaktadır. Bunun yanı sıra zamanla kimi daire sahiplerinin tadilat ve onarım amacıyla bazı bölümlerde yaptıkları yeniliklerde de geleneksel mimariye öykünme arzusunda olunmadığı görülmektedir. Hatta sitedeki bazı katların dış cephesinde tadilat sonucu ortaya çıkan beton çerçeve içindeki mermer söveli pencereler geleneksel dokuya bağlılıktan uzaklaşıldığını dahi göstermektedir.

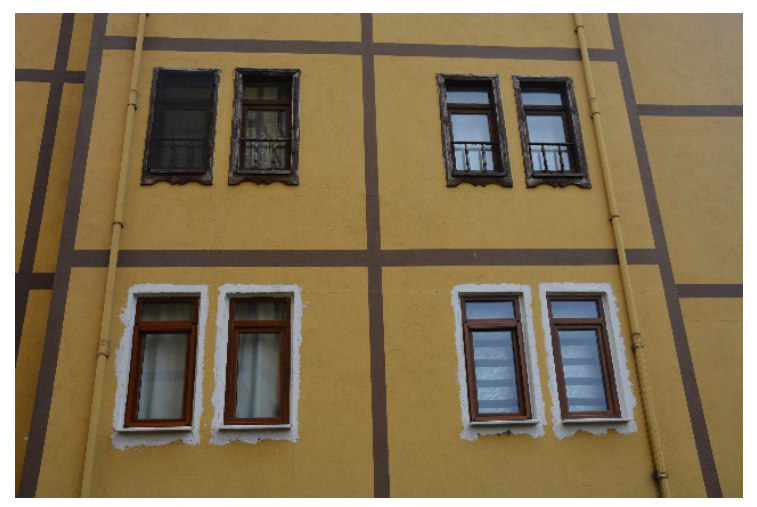

Fotoğraf 2. Göztepe Siteleri Cephe Detayı (kişisel arşiv)

Geleneksel dokunun yansımasına sahip diğer bir yaşam alanı ise Barış Mahallesi’ndeki Ermersa Sitesi (2006) ve yakınındaki Şehirkent Sitesi (2005)'dir. Bunlardan Ermersa Sitesi 2006 yılında tamamlanmıştır.

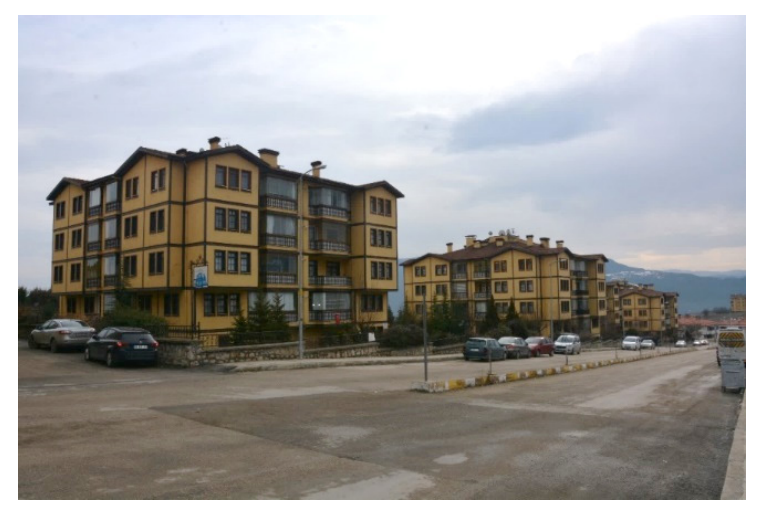

\section{Fotoğraf 3. Ermersa Sitesi Genel Görünüş̧ (kişisel arşiv)}

Mimari plan ve uygulama bakımından birbirini tekrar eden 6 bloktan oluşan Ermersa Sitesi; oyun parkı, otopark ve peyzaj düzenlemesine sahiptir. Bloklar, bodrum üzerine dört katlıdır. Zemin kattan sonraki üç kat hem köşelerden hem de yanlardan dışa taşkın görünümleriyle geleneksel Safranbolu evlerinin çıkma oda düzenlemesindeki cephe etkisini yansıtmaktadır. Çıkma biçiminde düzenlenen odalar üstte üçgen alınlıkla tamamlanmıştır. Ermersa bloklarındaki pencere düzenlemesi, çıkmalar ile çatı dikkat çekici geleneksel özellikler göstermektedir. Katları ve daireleri sınırlayan ahşap şeritler ile yan yana sıralanan ikili ve üçlü ahşap pencereler geleneksel vurguyu artırmış olsa da iç mekân düzenlemesinde geleneksel mimariye öykünülmemiştir. 
Ermersa Sitesi'yle komşu olan Şehirkent Sitesi de Ermersa Sitesi’nde görülen geleneksel dokunun cephelerde uygulama planlamasına oldukça benzerdir. İki site arasindaki en belirgin fark cephelerinde tercih edilen renk dokusudur.

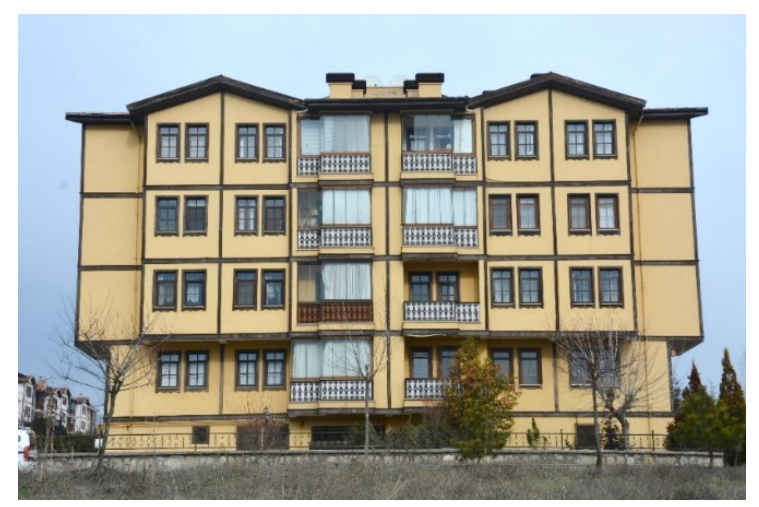

Fotoğraf 4. Ermersa Sitesi Detay (kişisel arşiv)

Ermersa Sitesi'nde tercih edilen renk, geleneksel Safranbolu evlerinin sivasiz olan birçoğundaki ahşap ve kerpiç dokunun oluşturduğu renk ilişkisi ile daha uyumludur. Şehirkent Sitesi ise sıvalı ve boyalı geleneksel Safranbolu evlerinin dokusuna uyarlanmıştır.

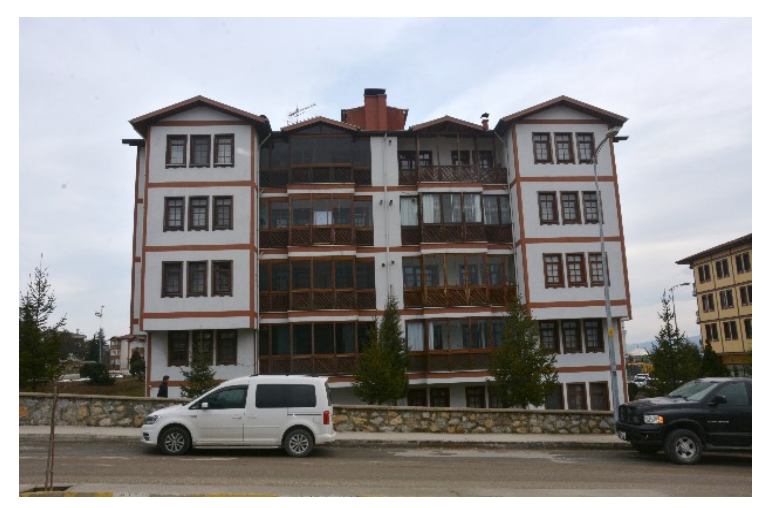

Fotoğraf 5. Şehirkent Sitesi Genel Görünüş (kişisel arşiv)

Geleneksel mimariye öykünme içeren bir diğer site de Çimkent (2002-2004) bloklarıdır. Dört bloktan oluşan site modern malzemeden yapılmıştır ve cephelerinde geleneksel mimariye güçlü bir öykünme içermektedir.

Ana yapı malzemesi beton, demir ve brikettir. Çatı konstrüksiyonu dışındaki ahşap malzeme ise özellikle cephelerde geleneksel öykünmeye atıfta bulunmak için dekoratif amaçla kullanılmıştır. Bloklardan biri tek daire üzerine diğer üç tanesi ise çift daire üzerine dört kat şeklinde inşa edilmiştir. Yapının giriş cephesi geleneksel Safranbolu evlerinin ön cephesindeki zeminden yükseltilen çıkmaya (cumba) öykünme içerir. Ön cephedeki bu vurgu blokların tüm cephelerinde devam etmektedir. Blokların temeli, geleneksel Safranbolu evlerinin temeline atıfta bulunacak şekilde moloz taş görünümlüdür. İç mekânda ise geleneksel mimariye öykünme görülmez. 


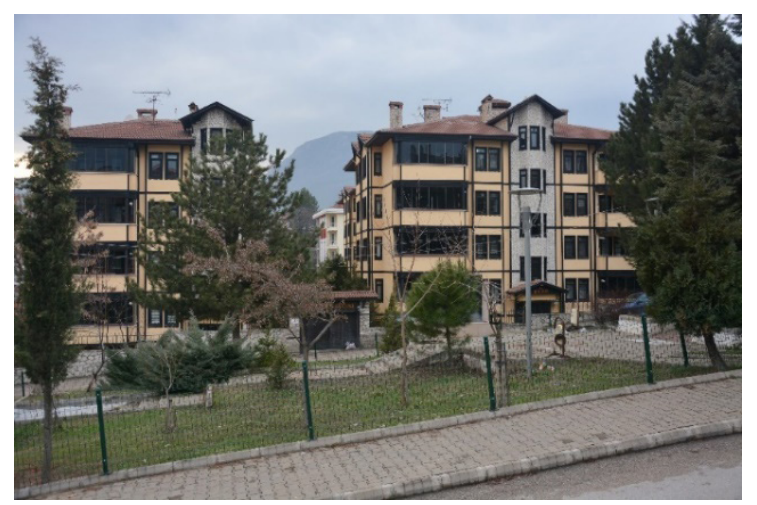

Fotoğraf 6. Çimkent Sitesi Genel Görünüşs (kişisel arşiv)

\section{Geleneksel Etkide Yaptırılan Villa Tipi Siteler}

Safranbolu'da çok katlı yapılar dışında villa tarzında siteler de inşa edilmiştir. Bu siteler genellikle iki dairenin birleştirilmesiyle oluşturulmuş tripleks yapılardır.

Villa tipi siteler, ekonomik koşulları iyi olan ailelere ferah bir iç mekân ve çevrenin yanı sıra güvenlikli bir yerleşim yeri oluşturmak için dizayn edilmişlerdir. Site biçiminde inşa edilen villa tipi yerleşim yerlerine Babasultan Mahallesi’ndeki Akçasu Konakları (2013-2014) ile Bağlarbaşı Mahallesi Aslanlar Mevkii’ndeki Şirintepe Villaları (1993-1996) örnektirler.

Akçasu Konakları dikdörtgen bir alana karşılıklı konumlandırılmış 10 bloktan oluşur. Her blok birbirine bitişik iki villadan oluşmaktadır. Böylece toplamda 20 ailenin barındığ 1 bu site, modern mekân düzenlemesine sahip geleneksel mimariden öykünmüş bir yerleşim yeridir.

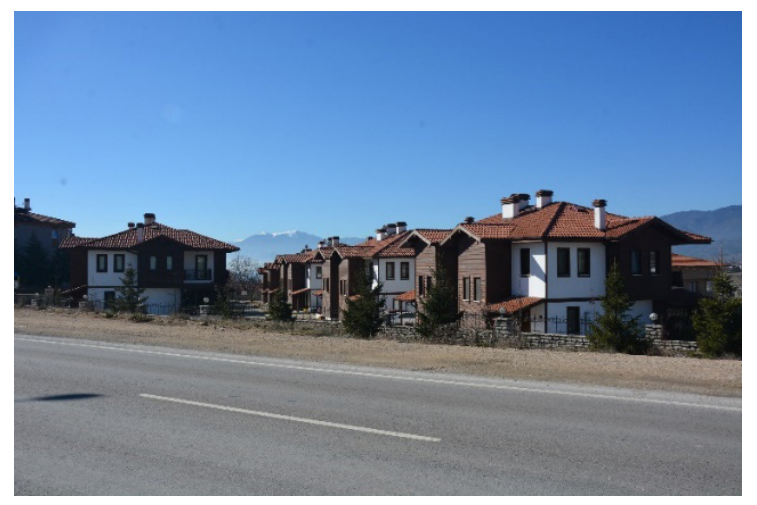

Fotoğraf 7. Akçasu Konakları Genel Görünüş (kişisel arşiv)

Akçasu Konakları (2013-2014) beton, demir ve briket gibi günümüz yapı malzemelerinin yanı sıra ahşap ve çatı kiremitleri gibi geleneksel yapı malzemelerinin birlikte kullanıldığı bir sitedir. Bu sitede ahşap malzeme ve çatı kiremitleri geleneksel mimariye öykünme amacının birer parçası olarak karşımıza çıkmaktadır. Giriş sundurmaları, çıkma oda şeklinde düzenlenen ahşap malzeme ile kaplanmış ön ve yan cepheler, yan yana sıralanan dikdörtgen pencereler ve antik üçgen alınlıklı çatılar 
geleneksel Safranbolu konaklarına öykünme içeren ögelerdir. Modern balkon düzenlemelerindeki ahşap malzeme kullanımı ve pencere düzenlemesi geleneksel ile modern çizgileri bir araya getirme çabasının örnekleridir.

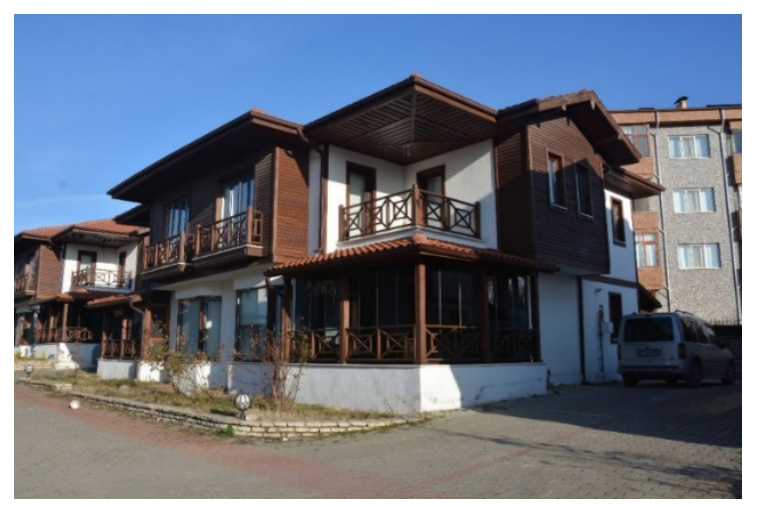

Fotoğraf 8. Akçasu Konakları Detay (kişisel arşiv)

Akçasu Konakları̉nın iç mekânında geleneksel dokuya öykünme yoktur.

Geleneksel Safranbolu evlerine öykünen bir diğer site ise inşaat mühendisi Hasan Erol tarafından yapılan Şirintepe Villaları'dır (1993-1996). Şirintepe Villaları, dairesel bir planlama içinde yan yana sıralanmıştır. Çift villadan oluşan bloklar toplamda 7 adettir. Bunun yanı sıra sitede kazan dairesi, toplantı odası ve görevli dairesini içeren ek bir villa da bulunmaktadır.

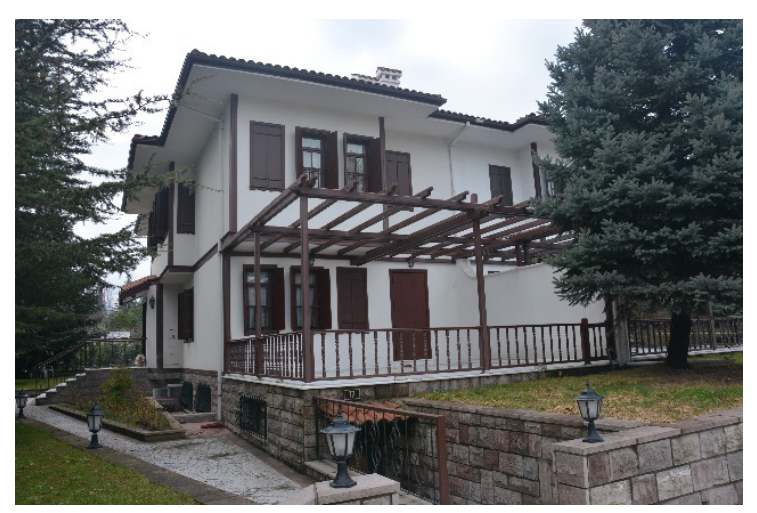

Fotoğraf 9. Şirintepe Villaları Detay (kişisel arşiv)

Şirintepe Villaları modern mimari teknik ve günümüz malzemeleri ile inşa edilmiştir. Taş temel üzerine inşa edilen tripleks villalar hem cephe ve çatı düzenlemesi ile hem de dış cephede kullanılan malzeme ve uygulanan yöntemlerle geleneksel mimari anlayışa öykünme çabasındadır. Cephe düzenlemelerinde geleneksel dokuya öykünmenin en görünür olduğu unsurlar çıma ve pencerelerdir. Ahşap kanatlı (kara kapak), ikili ve üçlü pencere düzenlemeleri, yapıların cephelerindeki geleneksel mimarinin etkisini belirgin şekilde gözler önüne serer. Bunun dışında yan cephelere bakan odaların çımaları ve geniş saçaklar geleneksel Safranbolu mimarisinin etkisini güçlendirir. 


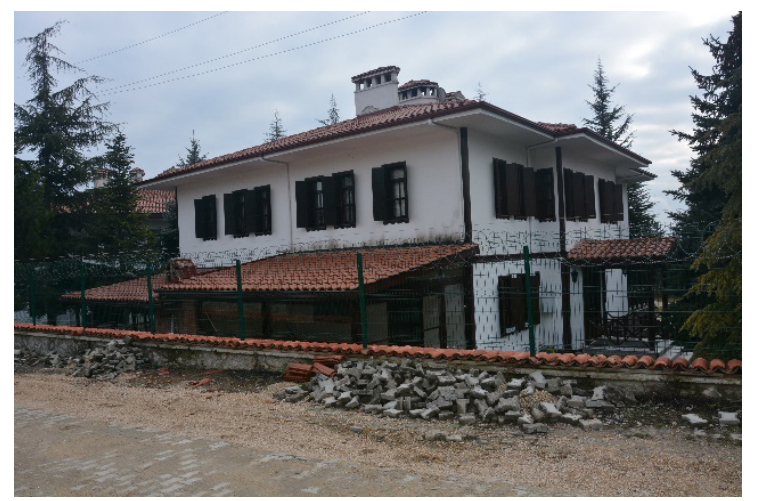

Fotoğraf 10. Şirintepe Villaları Detay (kişisel arşiv)

Şirintepe Villaları'nın diş mimarisinde geleneksel vurguyu belirgin kılmak için yapılan pencerelerdeki malzeme ve çizgisel uygulamalar geleneksel etkiyi iç mekânda da sürdürür. $\mathrm{Bu}$ düzenlemelerin sürdürdüğü etki dişında iç mekânda geleneksel Safranbolu evlerine öykünme yoktur.

\section{Geleneksel Etkide Yaptırılan Bağımsız Konak, Apartman ve Villalar}

Safranbolu'da bağımsız konak ya da villa şeklinde inşa edilmiş yapılardan Derya Sarıaltın Coşkun Konağı (2010), Zekine Ali Çıkrıkçıŏlu Villası (2008-2010) ile Ermersa Konak (2006) adlı apartman bu başlık altında incelenmiştir. Bunlardan Derya Sarıaltın Coşkun Konağı (2010) ile Zekine Ali Çıkrıkçıŏlu Villası (2008-2010) sit alanında olup, Ermersa Konak (2006) adlı apartman ise sit alanı dışında ancak etkileşim alanındadır.

Sit alanı içinde yer alan Derya Sarıaltın Coşkun Konağı’na 2010 yılında Ankara Kültür ve Tabiat Varlıklarını Koruma Kurulu’nun onayı ile yapı kullanma izni verilmiştir.

Konak, genel özellikleri itibariyle geleneksel Safranbolu evlerine güçlü bir öykünme içerir. Zemin üzerine 2 katlı inşa edilen konağın özellikle dış cephe uygulamaları geleneksel mimari karakteri güçlü bir şekilde yansitır. Üç köşeli cumba ile çıkma oda düzenlemeleri, yan yana sıralanan ikili ve üçlü ahşap çerçeve dekoruna sahip çift kanatlı ahşap kapaklı (kara kapak) pencereler, yapının katlarını belirleyen ahşap

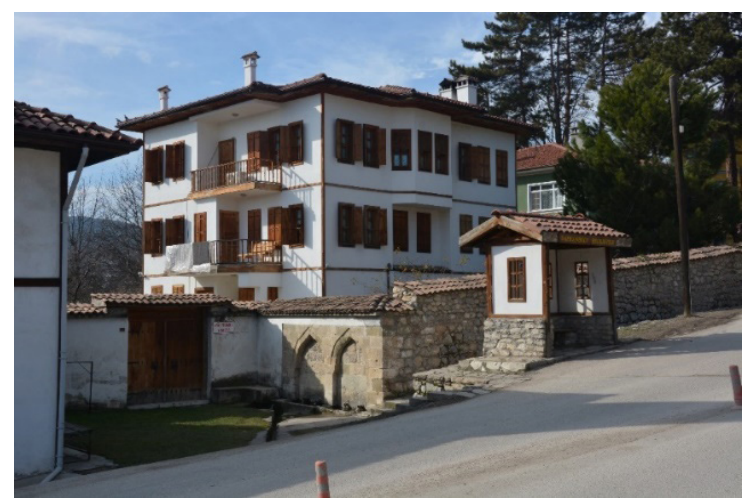

Fotoğraf 11. Derya Sarıaltın Coşkun Konağı (kişisel arşiv) 
şeritler ve geniş saçaklar ile kiremit çatı örtüsü geleneksel mimari karakteri bir bütün olarak yansıtır. Yapının geleneksel Safranbolu evlerinden ayrışan yönü beton, demir ve briket gibi günümüz yapı malzemeleri kullanılarak modern teknikle inşa edilmiş olmasıdır. Konağın hem cephelerinde hem de iç mekânında geleneksel mimariye bağlı kalma çabalarının bir sonucu olarak ahşap malzemeye geniş yer verilmiştir.

Yapının cephesindeki cumba, ana caddeye dönük olması yönüyle de geleneksel özellikler gösterir. Balkonlardaki ahşap korkuluklar ile cepheyi yatay ve dikey çevreleyen ahşap şeritler mimari açıdan geleneksel dokuya bağlı kalma zorunluluğunu modern yorum içinde eriterek geleneksel dokuyu her cephede göz önüne serer.

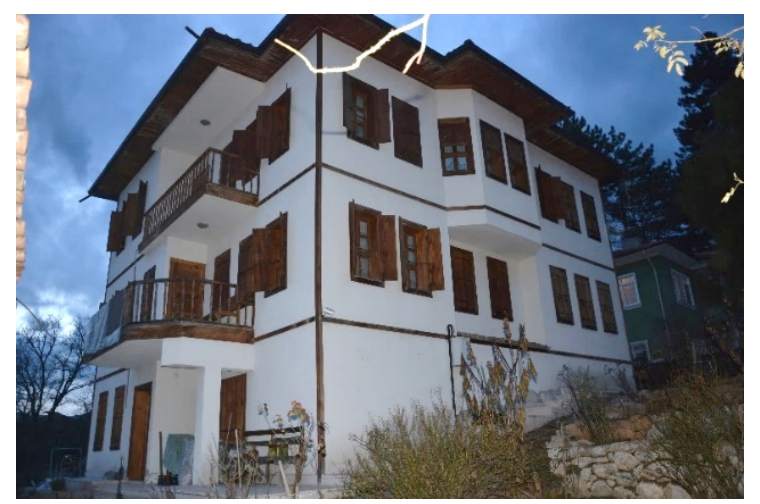

\section{Fotoğraf 12. Derya Sarıaltın Coşkun Konağı (kişisel arşiv)}

İç mekânda da geleneksel unsurların mimaride uygulandığını görmekteyiz. Bu uygulamalar özellikle ahşap tavan örtüsünde görünür olmuştur. Zemin döşemesinde uygulanan parkeye de ahşap görünüm verilerek geleneksel etkiyi koruma amacı güdülmüştür. Salondaki şömine, modern ve geleneksel unsurları bir araya getiren bir yorumla ele alınmıştır. Dış cephede geleneğe bağlı kalmada önemli bir işlev gören pencere düzenlemeleri iç mekânda da geleneksel etkiyi sürdürmektedir. Ancak yapının açık mutfak-salon uygulaması modern bir tasarım ve düzenleme içindedir.

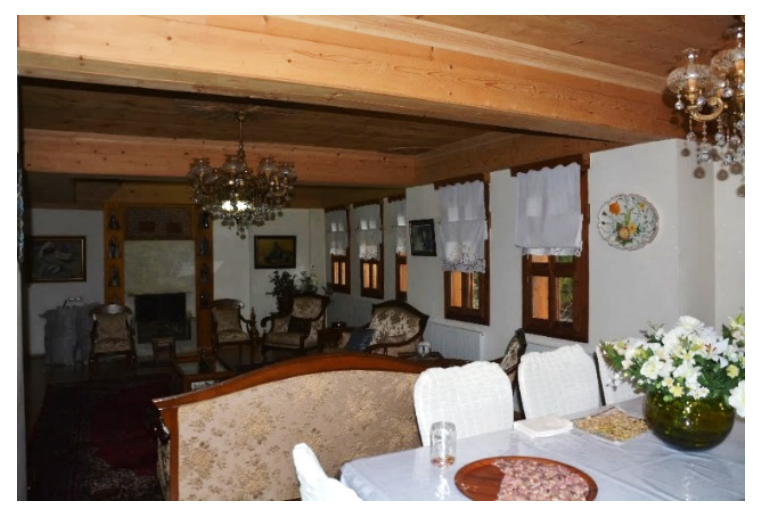

Fotoğraf 13. Derya Sarıaltın Coşkun Konağı İç Mekân Detayı (kişisel arşiv)

Konağın ikinci katı sofa biçiminde düzenlenmiş olup kattaki eyvan, ana yola bakan cepheden dişa taşan çıkma şeklindedir. Çıkma üç cephelidir ve geleneksel mimariye uygun olarak her cephesinde pencere açıklıklarına yer verilmiştir. İç dekorda duvar- 
lar boyunca uzanan seki biçiminde düzenlenen sedirler ve geleneksel örtüler ile artırılan etki, geleneksel Safranbolu evlerinin iç mekân düzenlemesinin etkisini özellikle ikinci kata güçlü bir şekilde taşımaktadır.

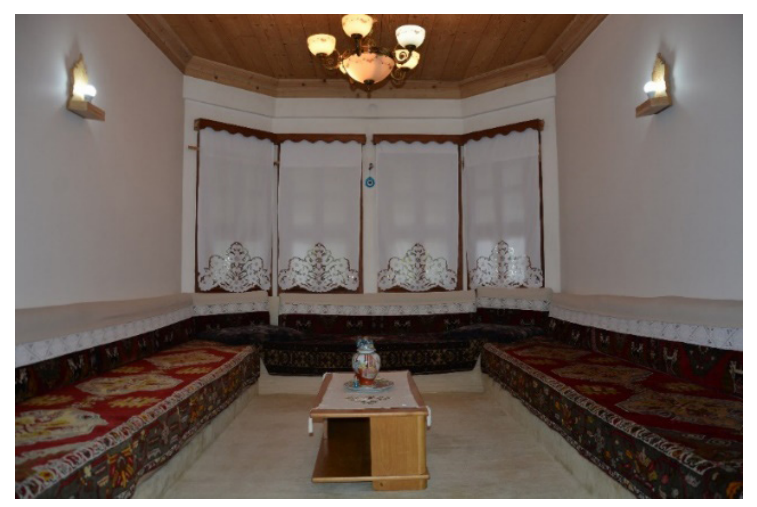

Fotoğraf 14. Derya Sarıaltın Coşkun Konă̆ı İ̧ Mekân Detayı (kişisel arşiv)

Sit alanına inşa edilmiş Z. A. Çıkrıkçıŏglu Villası da geleneksel dokuya uygun bir şekilde tasarlanmış olup, günümüz mimari yapı malzemeleri ve teknikleri uygulanarak inşa edilmiştir.

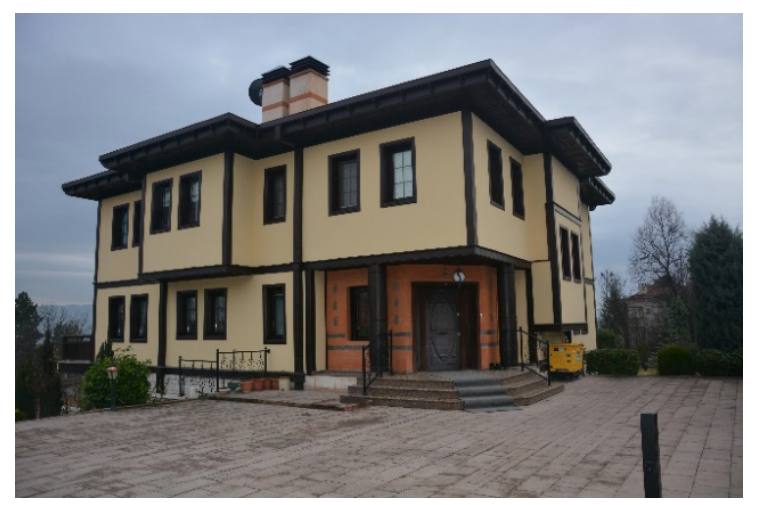

Fotoğraf 15. Z. A. Çıkrıkçıoğlu Villası (kişisel arşiv)

Yapının tüm cephelerinde geleneksel dokuya atıf söz konusudur. Çıkma odalar, çıkmaların her cephesinde yer alan pencereler, iki sıra dikdörtgen pencere düzenlemeleri, yapının kat ve cephe sınırlarını belirleyen ahşap şeritler, geniş saçaklı ve kiremitli çatı örtüsü villanın geleneksel konaklara öykünülerek gerçekleştirilmiş ögeleridir. Böylece yapının dış cephesindeki mimari uygulamalar yapıya geleneksel bir görünüm kazandırmıştır. 


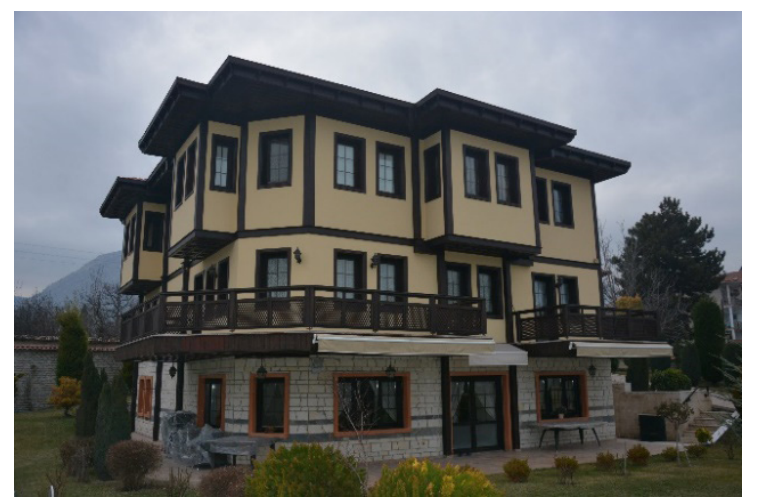

Fotoğraf 16. Z. A. Çıkrıkçıoğlu Villası (kişisel arşiv)

Z. A. Çıkrıkçığlu Villası'nda pencerelerin konum ve biçimsel özelliklerinin iç mekânda yarattığı etki ile hol tavanlarında kullanılan ahşap malzeme haricinde geleneksel Safranbolu evlerinin iç mekânına öykünme görülmez.

Sit alanı dışında olmakla birlikte etkileşim bölgesinde yer alan geleneksel dokudan öykünmüş bir diğer yapı da Ermersa Konak (2006) adlı apartmandır. Bu yapının cephesi bir bütün olarak geleneksel Safranbolu kent dokusuna uygun mimari anlayışta inşa edilmiştir. Yapı, zemin üzerine üç katlıdır. Katlar zeminden dışa taşkın çıkma formunda ve geleneksel mimariye öykünülen eli böğründelerle desteklenmiştir.

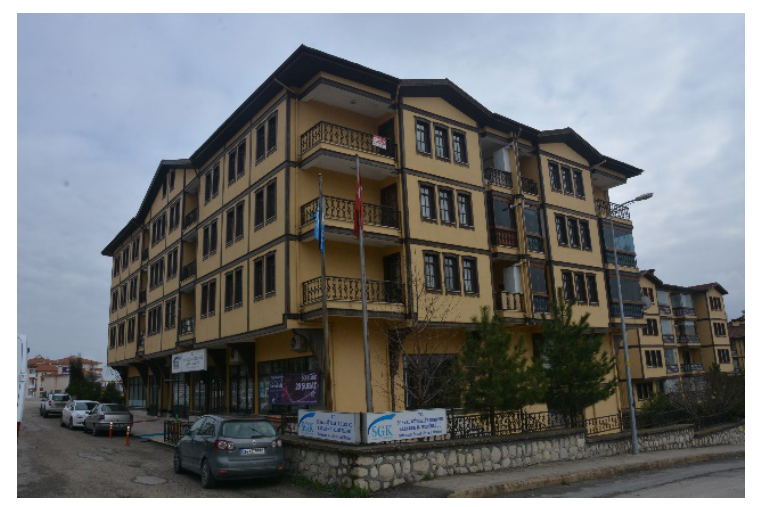

Fotoğraf 17. Ermersa Konak Apartmanı (kişisel arşiv)

Yapının üçgen çatı alınlıkları, çıkma odaları, ikili ve üçlü dikdörtgen ahşap çerçeveli pencereleri, katları yatay ve dikey yönde sınırlayan ahşap şeritleri geleneksel Safranbolu evlerine öykünme içermektedir. Ancak yapının iç mekânında geleneksel Safranbolu evlerine öykünme yoktur.

\section{Kamu Kurumları ile Yarı Özerk ve Özerk Kurumlar Tarafından Geleneksel Etki- de Yaptirilan Yapilar}

Safranbolu'da birkaç farklı nedene bağlı olarak geleneksel mimari unsurlara sahip kamu niteliğindeki yapılar inşa edilmiştir. Bu makalede bütünüyle kamu niteliğinde 
olmasada özerk ya da yarı özerk nitelikteki kurumlar tarafından yaptırılan yapılar da kamu niteliğindeki yapılar başlığı altında toplanmıştır. Geleneksel Safranbolu evlerine öykünülerek yapılan ve bu çalışma kapsamında incelenen kamu binaları; Adalet Sarayı, Sunal Tülbentçi Öğretmenevi ve Akşam Sanat Okulu ile Postane binasıdır. Yarı özerk ve özerk kurumlar tarafından inşa edilen yapılar; Safranbolu Fethi Toker Güzel Sanatlar ve Tasarım Fakültesi, Safranbolu Otogarı, Türkiye Emekliler Derneği Safranbolu Şube Başkanlığı, Belediye Kültür ve Turizm Danışma Merkezi (Beyaz Masa), Perşembe Pazarı (Köylü Pazarı), Minibüs Durakları ve Özel Konak Kız Yurdu'dur.

\section{Kamu Kurumları Tarafından Geleneksel Etkide Yaptırılan Yapılar}

Kamu yapıları kimi zaman dönemin sosyal ve siyasal gelişmelerinin politik yansımalarını ortaya koyan bir yaklaşımın ürünü olabilmektedir. 25 Haziran 1992 tarihinde çıkarılan 204/8 sayılı KHK ile yeni inşa edilecek Adalet Sarayları’nın çağın gelişmelerine, yargının saygınlık ve ciddiyetine uygun; kaliteli, iyi işleyen ve geleceğe dönük olarak planlanan modern ve geleneksel Türk Mimarisi’ne uygun bir şekilde yapıldığ ve yapılmaya devam edileceği belirtilmektedir ${ }^{31}$. Benzer şekilde günümüz siyasi erkinin birçok kentte yöresel üslubun yanı sıra Selçuklu ve Osmanlı mimari estetiğini öne çıkaracak yapılara öncelik verileceğini ifade eden 2018 tarihli Cumhurbaşkanlığ 1 Seçimleri ve Genel Seçimler Seçim Beyannamesi de buna örnektir ${ }^{32}$. Bu durum tüm siyasal dönemler için geçerlidir. Bu bağlamda işlev açısından Adalet Sarayları́nın kentlerinin en önemli kamu kurumlarından biri olarak öne çıkması, siyasal düşünce biçimine uygun olduğu düşünülen mimari anlayışların bu yapılara yansıtılması sonucunu doğurmuştur. Özellikle Safranbolu Adalet Sarayı da geleneksel mimari yansımaların oldukça güçlü bir şekilde gözlemlenebildiği bir yapıdır. Yapı, Selçuklu ve Osmanlı Dönemi mimari karakterini yansıtan özelliklerini yöresel tarihi kent dokusu ile buluşturmuştur. Adalet Sarayı'nın pencere düzenlemeleri ile çatı uygulaması bölgeye özgü bir üsluba sahiptir. Yapının diğer mimari özelliklerinde Selçuklu ve Osmanlı mimarisine seçmeci anlayışta bağlı kalma çabaları görülmektedir. Bu durum I. Ulusal Mimarlık Dönemi’nin anlayışını anımsatmaktadır. Ancak bu kez seçmeci anlayış, mimari yapının cephelerine daha yoğun bir şekilde uygulanmıştır.

Milli Eğitim Bakanlığı’nca inşa edilen Sunal Tülbentçi Öğretmenevi ve Akşam Sanat Okulu binasında ise Safranbolu'daki diğer kamu yapılarına kıyasla geleneksel mimariye öykünme oldukça zayıftır. Yapının ön ve yan cephelerindeki çıkmalar, pencere düzeni ve çatı malzemeleri dışında geleneksel mimariden etkilenme

31 "Yöresel Mimarisinin Adalet Saraylarındaki İzleri”, haz., Gökçe Aras, erişim 12 Ocak, 2019, http://v3.arkitera. com/h13461-yoresel-mimarinin-adalet-saraylarindaki-izleri.htmlArkitekt.

32 Cumhurbaşkanlığ Seçimleri ve Genel Seçimler Seçim Beyannamesi, Ankara: Ak Parti Genel Merkezi, erişim 10 Ocak, 2018, s.270. http://image.yenisafak.com/resim/Beyanname23May\%C4\%B1s18_icSayfalar.pdf. 


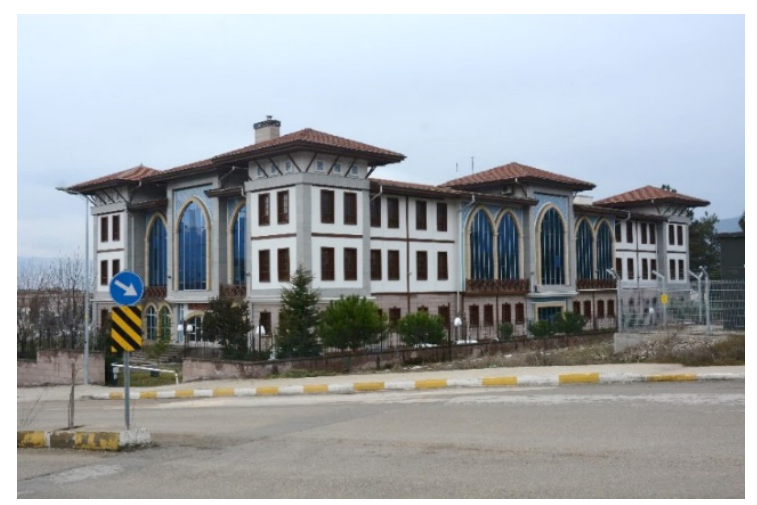

Fotoğraf 18. Adalet Sarayı (kişisel arşiv)

yoktur. Mimar, ön ve yan cephelerde uyguladığı çıkmalarda yalnızca çıkmanın ön cephesini sade ve geniş pencere açıklığına yer vererek değerlendirmiştir. Bu durum yapıda geleneksel mimariye bağlı kalma isteğinin daha aydınlık bir ortam oluşturma beklentilerinin gerisinde kaldığını ortaya koymaktadır. İç mekânda ise geleneksel dokuya öykünme yoktur.

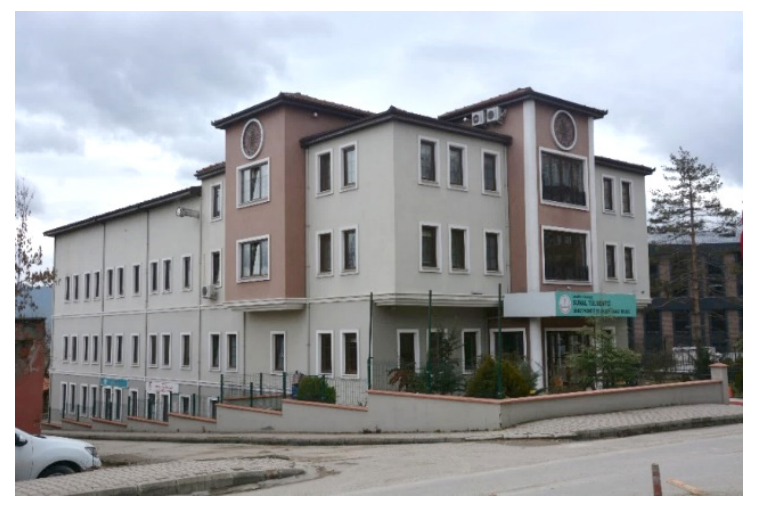

Fotoğraf 19. Sunal Tülbentçi Öğretmenevi ve Akşam Sanat Okulu (kişisel arşiv)

Postane binası da Sunal Tülbentçi Öğretmenevi'ne benzer şekilde geleneksel Safranbolu evlerine sınırlı öykünme içeren bir yapı olarak karşımıza çıkmaktadır. Postanenin lojman olarak planlanan üst katlarındaki çıkma oda tasarımı ve pencere düzenlemeleri geleneksel mimarinin özellikleri baz alınarak yorumlanmıştır ancak, pencere düzenlemelerinin geleneksel dokuya öykünme çabası, salonun yeterince sşık almasına engel olmuştur. Bu sorun pencere düzenlemesi yapılırken yapının kapsadi$\breve{g}_{1}$ alan ile pencere ölçüleri arasındaki oranın yeterince dikkate alınmadığını gösterir. Böylece geleneksel dokuya atıf yapma kaygısı günümüzün gereksinimleriyle örtüşmeyecek sonuçlar doğurmuş ve mimari bir sorunsala neden olmuştur.

Yapının iç mekânında ise pencere düzenlemelerinin dıştan içe yansıtılmasıyla oluşturulan etki dışında geleneksel dokuya ait herhangi bir mimari yorum yoktur. 


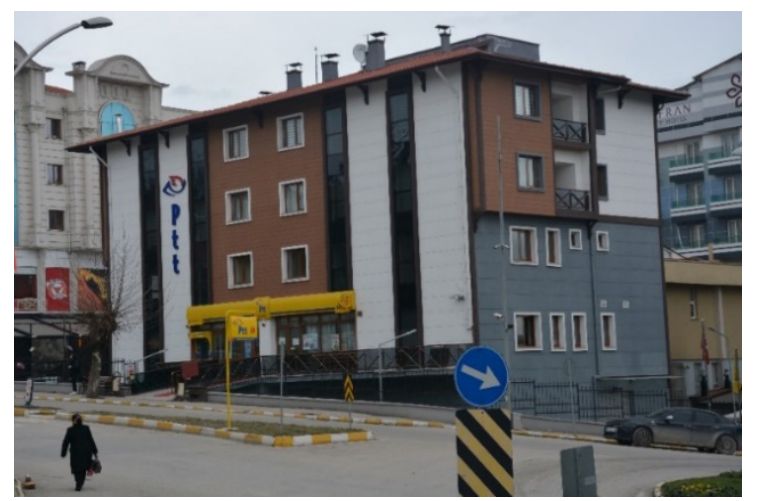

Fotoğraf 20. Postane Binası (kişisel arşiv)

\section{Yarı Özerk ve Özerk Kurumlar Tarafından Geleneksel Etkide Yaptırılan Yapılar}

Ülkemizde yarı özerk ve özerk nitelikteki kurumlardan başlıcaları üniversiteler, belediyeler, vakıflar ve dernekler gibi kuruluşlardır. Bu kurum ve kuruluşlar merkezi otoriteye bağlı olsalar da bazı hususlarda yarı özerk ve/veya özerk niteliğe sahiptirler. Bu nitelik kurumlara özellikle mimari yapıların inşasında bağımsız hareket etme olanağı sağlamıştır.

Karabük Üniversitesi Safranbolu yerleşkesindeki mimari tasarımını Aysun Özköse’nin ${ }^{33}$ yaptığı Fethi Toker Güzel Sanatlar ve Tasarım Fakültesi, geleneksel Safranbolu evlerine öykünme içeren diğer bir yapıdır. Yapıda geleneksel mimariye öykünülerek, zemin kat üzerine yükselen bölümler çıkma oda şeklinde tasarlanmıştır. Bunun yanı sıra çıkmaları destekleyen modern payandalar ahşap görünümlü olup geleneksel ahşap konsollara atıf içermektedir. Yapının çatı konstrüksiyonu, geniş saçakları ve iç mekânındaki bazı -geleneksel büyük çaplı konaklardaki havuzlara öykünülen- havuz görünümlü bölümler geleneksel dokuya atıf içerir. Bunun dışında iç mekâna yansiyan geleneksel etki yoktur.

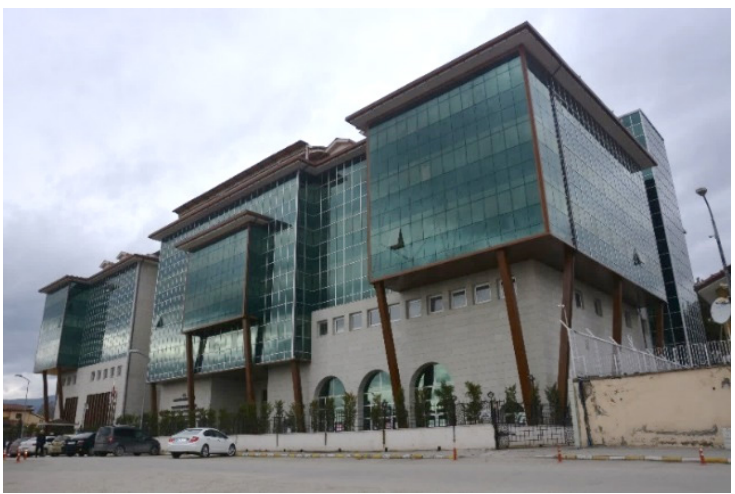

Fotoğraf 21. Fethi Toker Güzel Sanatlar ve Tasarım Fakültesi (kişisel arşiv)

33 Aysun Özköse, Fethi Toker Güzel Sanatlar ve Tasarım Fakültesi’nin inşa sürecinde, planlamaları dışında bazı beklenmedik etkenlerle karşılaşıldığını bundan dolayı bazı uygulamalarda ilk planlamanın dışına çıkıldığını belirtmektedir. 
Safranbolu Belediyesi’nin özellikle tarihi kentin UNESCO Dünya Kültür Mirası Listesi’ne alınmasından sonra inşa ettirdiği bazı yapılarda kentin tarihsel dokusuna öykünmeyi öncelediği görülür. Bu türden yapılardan biri Safranbolu Otogar’dır.

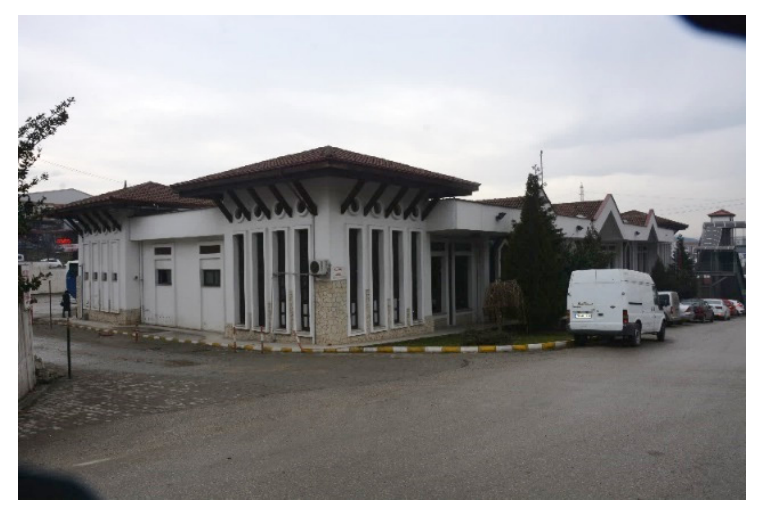

Fotoğraf 22. Safranbolu Otogar (kişisel arşiv)

Safranbolu Otogarı geleneksel mimari unsurlara sahip bir yapı izlenimi verse de yapının genel özelliklerine bakıldığında geleneksel etki oldukça zayıftır. Dikdörtgen planlı yapının köşe düzenlemeleri, geniş saçakları, ahşap şerit ve çatı örtüsü hem yapının en çarpıcı mimari unsurlarıdır hem de geleneksel özelliklerin nispeten mimari yapıda temsil edildiği bölümleridir. Bu bölümlerin yapının köşelerinde cepheden vurgulanmış olması, geleneksel dokunun göze daha fazla çarpmasına neden olmuştur. Özelde bakıldığında geleneksel unsurlara öykünme var olsa da geleneksel etki güçlü bir şekilde yapıya taşınamamıştır.

Belediyeye ait olan yapılardan bir diğeri de Türkiye Emekliler (İşçi) Derneği Safranbolu Şubesi’ne (2001) tahsis edilen ve Mimar Selahattin Karakök ile Mühendis Burhan Yılmaz tarafından inşa edilen yapıdır. Bina, modern yapı malzemelerinin geleneksel Safranbolu evlerine öykünülerek kullanıldığg bir yapıdır. Yap1, su deposu üzerine konumlandırılmış ve arazinin coğrafi yapısı da gözetilerek zemin üzerine iki katlı olarak inşa edilmiştir. Geleneksel Safranbolu evlerinin tamamında görülebilen ikili ve üçlü ahşap çerçeveli pencere düzenlemesi, ahşap şeritler, geniş saçaklar, çıkma oda ve destek unsurlarıyla bu yapı, geleneksel Safranbolu evinin adeta bir kopyasıdır.

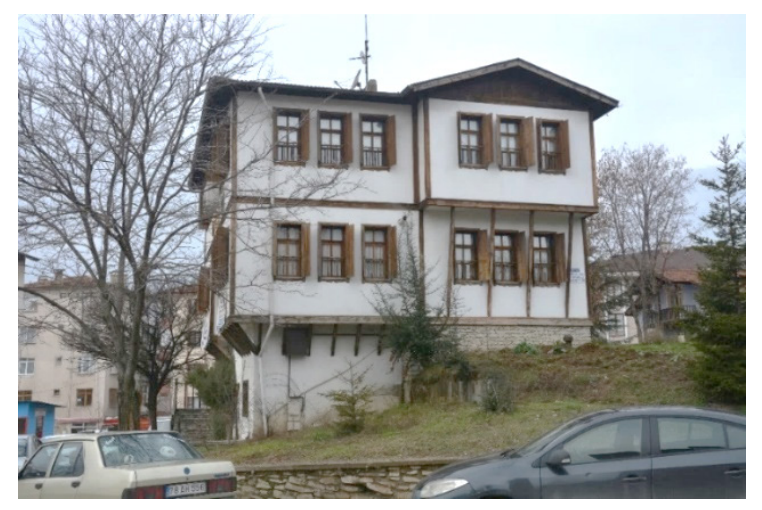

Fotoğraf 23. Türkiye Emekliler (İş̧i) Derneği Safranbolu Şubesi (kişisel arşiv) 
Derneğin iç mekânında da geleneksel mimariye öykünme vardır. Tavan ve yer döşemelerinde ahşap malzeme yerine modern konutlarda sıklıkla karşılaştığımız düzenlemeler görülse de odaların duvarları boyunca pencere hizasına kadar yükselen sedirler iç mekândaki geleneksel dokuya öykünmeye belirgin örnektirler.

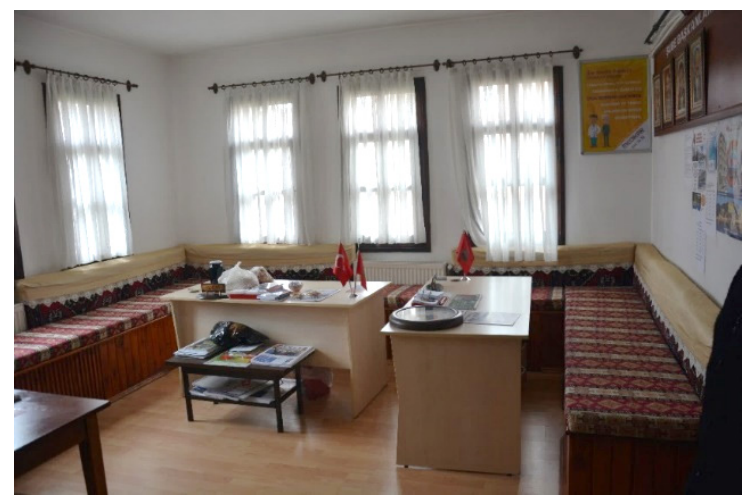

Fotoğraf 24. Türkiye Emekliler (İşçi) Derneği Safranbolu Şubesi İç Mekân Detayı (kişisel arşiv)

Belediye tarafından yaptırılan diğer bir yapı ise 'Beyaz Masa' olarak da adlandırılan Turizm Danışma Merkezi'dir. Yapı, Turizm Danışma Bürosu olmasından ötürü şehrin meydanına geleneksel Safranbolu evlerinin küçük bir modeli şeklinde inşa edilmiştir.

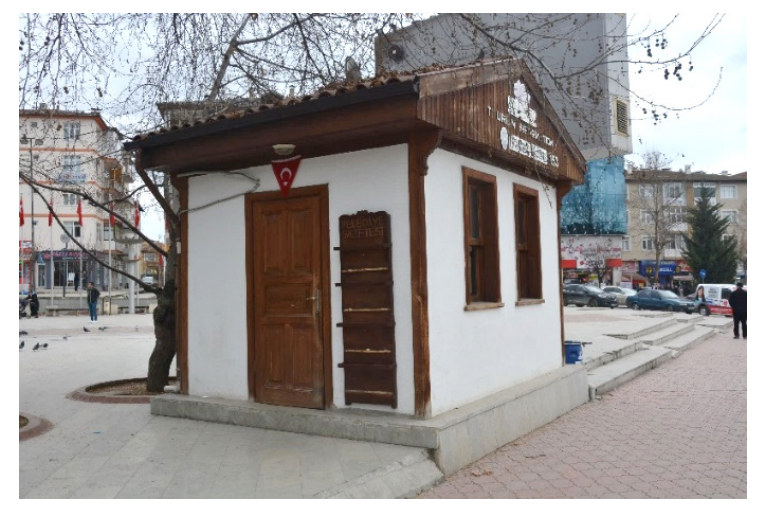

Fotoğraf 25. Turizm Danışma Merkezi (Beyaz Masa) (kişisel arşiv)

Belediyenin yaptırdığı diğer bir yapı da Perşembe Pazarı́na kurulan Köylü Pazarı adlı bölümdür. Kendi ürettikleri mahsulü satmaları için Perşembe Pazarı’nda köylülere tahsis edilmiş olan bölüm, Safranbolu geleneksel dokusuna öykünme içeren kapalı pazar yeri şeklindedir. Yapıdaki çatı örtüsü ile yoğun kullanılan ahşap doku geleneksel özelliktedir. 


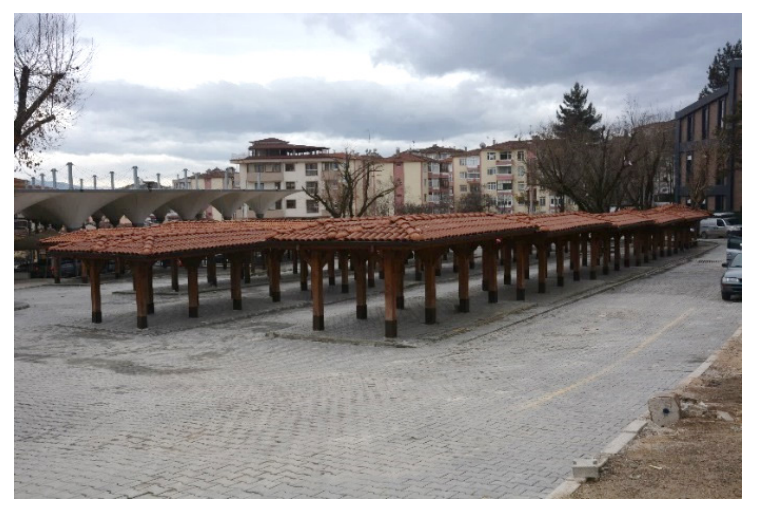

Fotoğraf 26. Perşembe Pazarı Köylü Pazarı Detayı (kişisel arşiv)

Köylü Pazarı́nın yanı sıra belediyenin özellikle ana arterlerde ve sit alanlarındaki yollarda sıkça yer verdiği geleneksel dokuya sahip duraklarda da Safranbolu geleneksel dokusuna öykünme vardır. Duraklar, Safranbolu evlerinin minyatür bir kesiti şeklinde tasarlanarak geleneksel dokuya atıf içerir.

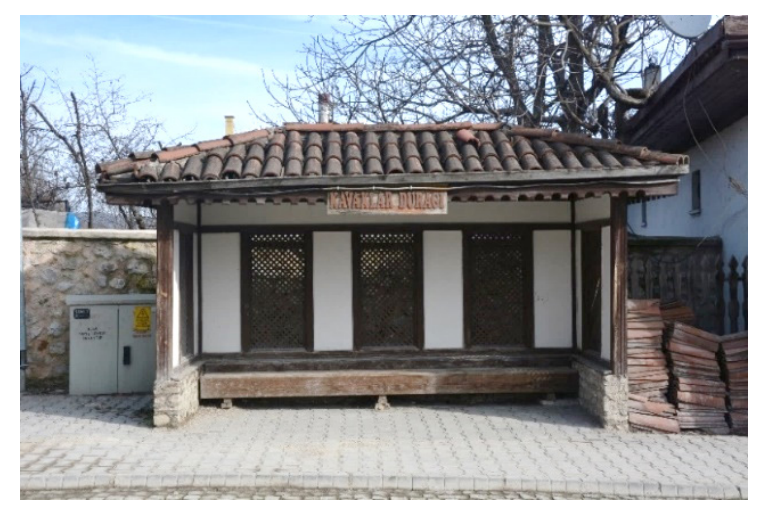

Fotoğraf 27. Minibüs Dură̆ı (kişisel arşiv)

Babasultan Mahallesi’ndeki Özel Konak Kız Yurdu Milli Eğitim Bakanlığı tarafından izin verilen özel bir vakfın işletmekte olduğu bir kurumdur. Özel yurt, mimar İsmail Akbulut tarafından 2007-2010 yılları arasında yapılmıştır.

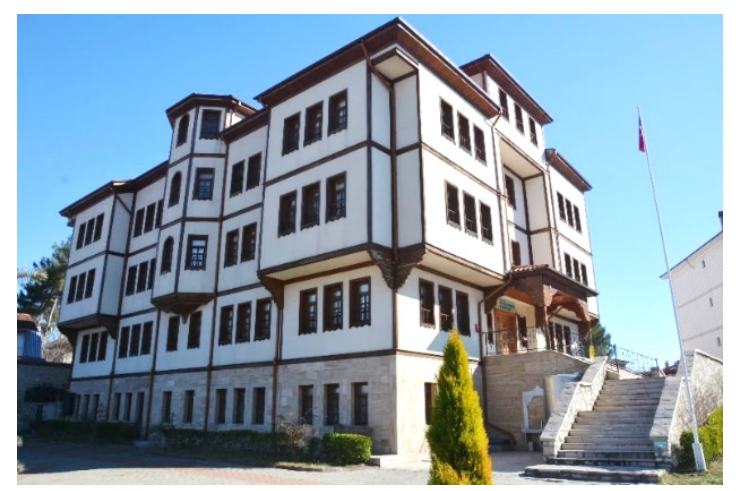

Fotoğraf 28. Özel Konak Kız Yurdu (kişisel arşiv) 
Yapı, sit alanı içinde değildir. Ancak tarihi Safranbolu şehrine (Eski Çarşı) hâkim bir noktada olduğundan çevresel etkileşim alanında yer almaktadır. Yurdun planlama ve uygulama aşamalarında mimari açıdan geleneksel Safranbolu dokusuna bağlı kalma çabaları görülmektedir. Yapı, modern mimari malzemelerle inşa edilmiştir. Beton, demir ve briket yapının temel inşa malzemeleridir. Bunlar dışında en fazla kullanılan malzeme ise ahşaptır. Ahşap özellikle yapının iç ve dış mimarisinde yoğun bir şekilde kullanılmıştır. Bu malzemenin tercih edilmesinin nedeni geleneksel dokuya bağlı kalma çabasıdır. Dış cephe planlamasında ikili ve üçlü dikdörtgen ahşap pencereler, cumba ve çıkma odalar, eli böğründeler, geniş saçaklar ile çatı konstrüksiyonunda geleneksel dokuya oldukça güçlü bir öykünme söz konusudur. Yapının iç mekânında da geleneksel dokuya bağlı kalma çabaları görülmektedir. Ahşap doğrama merdivenler, oda ve birimlerin tavan köşelerini çevreleyen ahşap şeritler buna örnektir. Bunların yanı sıra zemin döşemede ahşap görünümlü laminant uygulaması ile bazı birimlerdeki tavan göbekleri geleneksel dokuya öykünme içerir.

\section{Geleneksel Etkide Yaptırılan Ticari Yapılar}

Safranbolu İpek Yolu üzerine kurulmuş ve tarih boyunca oldukça önemli bir yerleşim yeri olmuştur. Kentin ana geçim kaynağını tarım ve hayvancılık oluşturmuş olsa da ticaret yolları üzerinde kurulu olması Osmanlı'dan günümüze değin kentin yaşam koşullarını olumlu yönde etkilemiştir. Bu durum Cumhuriyet'in ilanından sonra da devam etmiştir. Günümüzde doğal güzelliklerinin yanı sıra kentin koruma altına alınmasının ortaya çıkardığı olumlu sonuç, yerli ve yabancı turistlerin kente olan ilgisini artırmıştır. Buna bağlı olarak kentin ekonomisinde çeşitlilik ve canlanma söz konusu olmuştur. Kentin önemli gelir kaynağına dönüşen turizm, barınma koşullarının iyileştirilmesi ve çeşitlendirilmesi ihtiyacını doğmuştur. Bu ihtiyaç Karabük Üniversitesi'nin kurulması ile birlikte daha da artmıştır. 2000'li yılların başından itibaren özellikle iç turizmde kentin popüler bir yere sahip olmasıly birlikte konaklama ihtiyaçlarının karşılanması amacıyla hotel ve konaklar başta olmak üzere ticari yapılar nicelik olarak artmış ve nitelik bakımından gelişmiştir. Hotel ve konaklama dışında, yeme-içme mekânları ile dükkanlarda da nicelik olarak artış olmuştur. Geleneksel Safranbolu evlerinden öykünülerek inşa edilen ticari amaçlı yapılara Çeşmeli Konak, Bağlar Saray Hotel (2004-2007), Çelik Palas (1935), Hilton Garden Inn (2014-2016) ve Zalifre Otel (1998-2002) örnektirler.

Turistlerin konaklamaları amacıyla inşa edilmiş yapılarda bazı etkenlere bağlı olarak geleneksel dokunun mimari karakterinin uygulandığı görülmektedir. Ancak bu durum yapıların ticari beklentileri ve yapıldıkları yere göre değişiklik göstermektedir. Kentte, iç ve dış turizme dönük konaklama ihtiyacını karşılamak amacıyla yapılan hotel ve konaklar sayısal olarak oldukça fazladır. Bunlardan bazıları Osmanlı Devleti döneminde insanların gündelik yaşamlarını sürdürdükleri barınma amacıyla yapılmış evler iken, bölgenin turizmde önem kazanmasından sonra turistlerin konaklaması amacıyla ticari barınma mekânlarına dönüştürülmüşlerdir. Bunlara Asmazlar Konağ 1 ve Hacımemişler Konağı örnektir. Bu iki yapı günümüzde sadece turistik amaçla işletilmektedir. Sadece günümüzde turistik amaçla işletilmektedirler. Bunların dışında sit alanı olarak belirlenen bölgeye geleneksel dokuya bağlı kalınma şar- 
tıyla sonradan inşa edilen konaklar ile sit alanları dışında olmalarına rağmen geleneksel dokuya öykünmüş olan konaklar da vardır. Sit alanına sonradan yapılan konaklardan biri Hıdırlık Yokuşu üzerinde yer alan Çeşmeli Konak'tır. Konağın inşa edildiği yer Eski Çarşı olarak adlandırılan Osmanlı Devleti dönemi yerleşim yeridir.

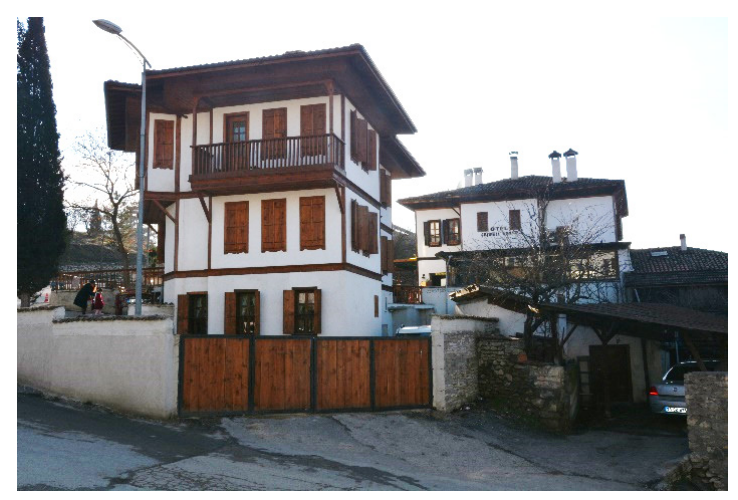

Fotoğraf 29. Hidırlık Yokuşundaki Çeşmeli Konak (kişisel arşiv)

Konağın kentsel koruma altındaki alana yapılmış olması çeşitli tartışmalara sebep olmuştur. Konak, cephe özellikleri bakımından geleneksel dokuya öykünülerek gerçekleştirilmiştir. Buna karşın konağın iç mekânındaki yüzeysel ve tutarsız uygulamalar geleneksel Safranbolu konaklarının mimari iç mekân düzenlemeleri ile çelişmektedir. Hıdırlık Yokuşu'nda yer alan Çeşmeli Konak, Eski Çarşı olarak isimlendirilen kentsel sit alanında olduğundan dolayı geleneksel mimari dokuya dış ve iç mekân düzenlemelerinde oldukça bağlı olması beklenen bir yapı olarak inşa edilmeliydi. Ancak dış cephede önemli oranda geleneksel dokuya öykünme görülse de konak bir bütün olarak kentsel sit alanına inşa edilmiş bir yapı uygunluğunda değildir.

Sit alanı içinde olmamakla beraber geleneksel mimari anlayışa bağlı kalınarak inşa edilen konaklardan biri de mimar Hadi Emiroğlu tarafından 2004-2007 yılları arasında inşa edilen Bağlar Saray Otel'dir.

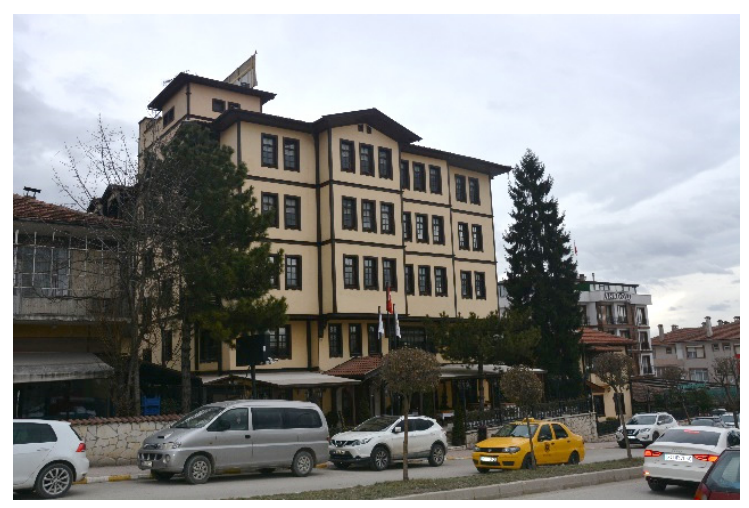

Fotoğraf 30. Beyaz Saray Otel (kişisel arşiv)

Otel, geleneksel Safranbolu evlerine bağlı kalınarak inşa edilmiştir. Zemin üzerine 3 katlı inşa edilen yapıya bir süre sonra yine geleneksel mimari unsurlara bağlı kalınarak bir bina daha eklenmiştir. Yapıdaki ikili ve üçlü pencere düzenlemeleri, çıkmalar, 
üçgen çatı alınlığı, katlar ile birimleri yatay ve dikey yönde belirleyen ahşap şeritler geleneksel mimari ögelere öykünme içerir.

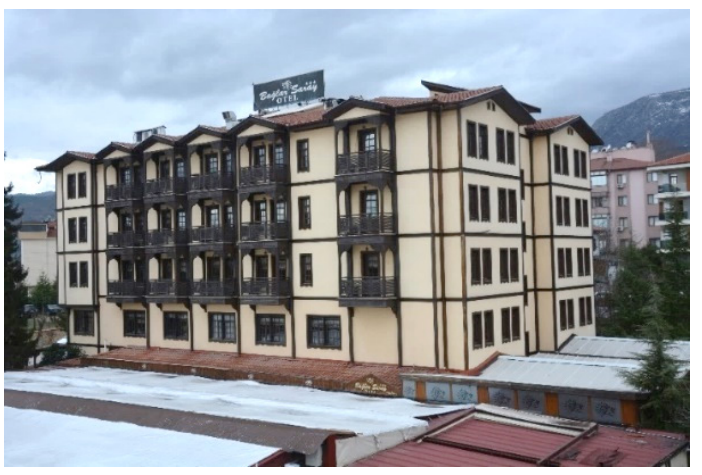

Fotoğraf 31. Beyaz Saray Otel (kişisel arşiv)

Otelin iç mekânında geleneksel mimariye bütünüyle bağlı kalmanın ekonomik külfetinden kaçınılarak bazı odalarda geleneksel dokuya öykünme daha güçlü bazı oda ve birimlerde ise zayıf tutulmuş olsa da çoğunlukla geleneksel dokunun modern yaşam koşullarına uyarlandığı görülmektedir.

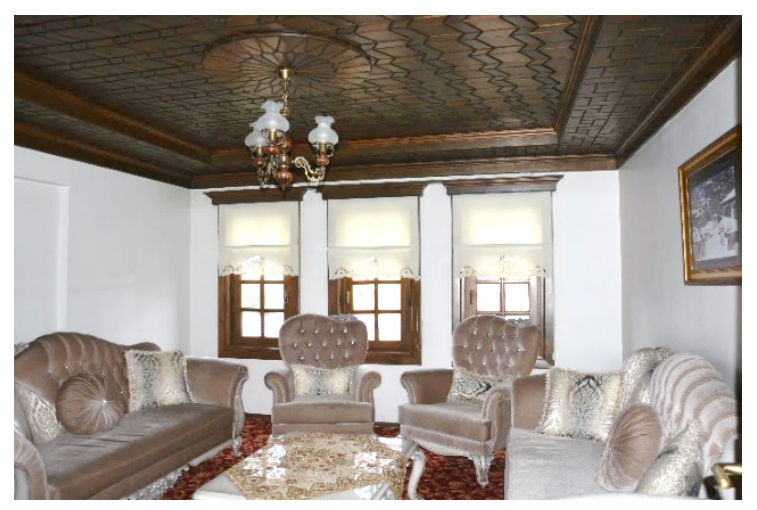

Fotoğraf 32. Beyaz Saray Otel İç Mekân Detayı (kişisel arşiv)

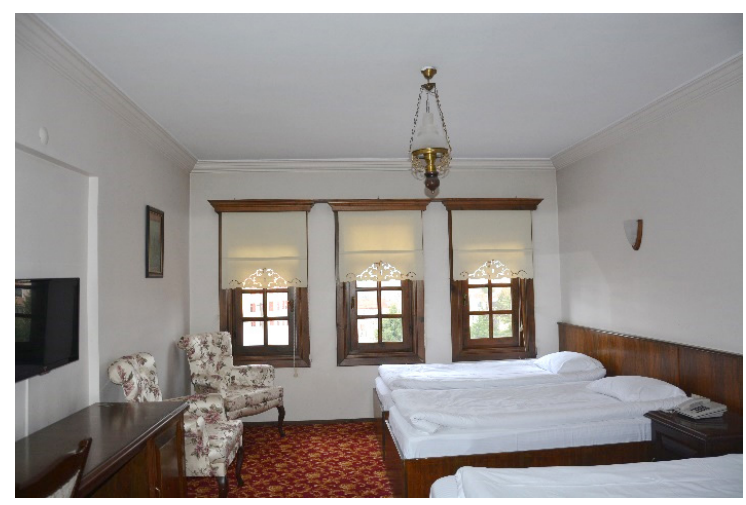

Fotoğraf 33. Beyaz Saray Otel İç Mekân Detayı (kişisel arşiv)

Safranbolu evlerine öykünülerek yapılan diğer bir hotel de Çelik Palas’tır. 3 Nisan 
1937 yılında Karabük merkezinde yapımına başlanan Demir Çelik Fabrikası’nı ${ }^{34}$ inşa etmek amacıyla Avrupa'dan ülkemize getirilen mühendislerin barınması amacıyla 1935 yılında Safranbolu'da inşa edilmiştir. Bu bakımdan Safranbolu'nun uluslararası kimliğini yansıtan ilk konaklama mekânı Çelik Palas’tır. Günümüzde hotel olarak kullanılan yapı, 1970'li yıllarda Safranbolu Hükümet Konağı’nın yanması sonucunda hükümet binası olarak da hizmet vermiştir. 1979-80 yılları arasında da siyasal karşılıklarda iç mekân tahrip olmuş ve yeniden ele alınmıştır. 1999 yılında son haline kavuşmuştur. Yapı, Avrupalı mühendislerin konaklama ihtiyaçlarını karşılama amacıyla devlet tarafından yaptırıldığı için özenle ele alınmıştır. Yapının dış ve iç mekânındaki mimari karakter, tamamıyla geleneksel Safranbolu evlerine uygundur.

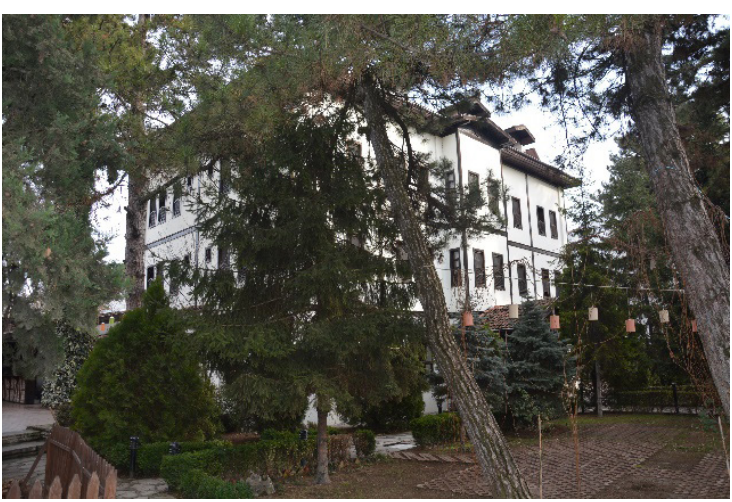

Fotoğraf 34. Çelik Palas Hotel (kişisel arşiv)

Yapının tavan ve yer döşemeleri ile merdivenlerinde nitelikli ahşap kullanılmıştır.

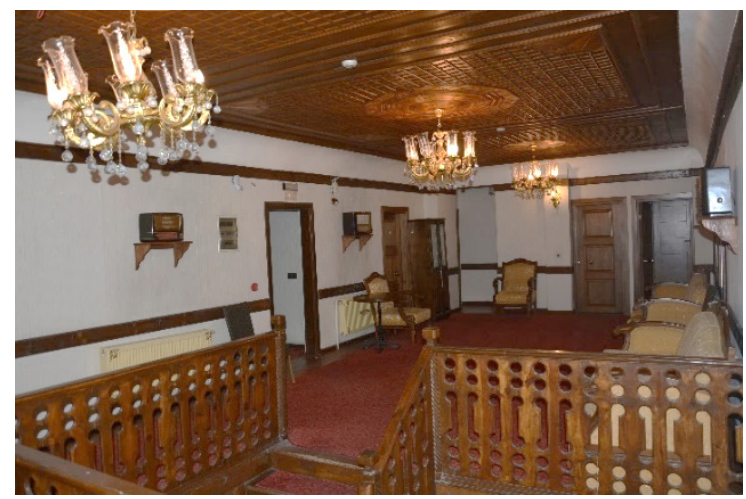

Fotoğraf 35. Çelik Palas Hotel İç Mekân Detayı (kişisel arşiv)

34 Nazım Yılmaz, "Arşiv Belgeleri Işı̆̆ında Karabük Şehri ve Karabük Demir Çelik Fabrikası Tarihi Süreci”, Kuruluşundan Bugüne Karabük ve Demir Çelik Sempozyumu, 2-3 Nisan 2010, Ankara, 2010, s.1-16. 


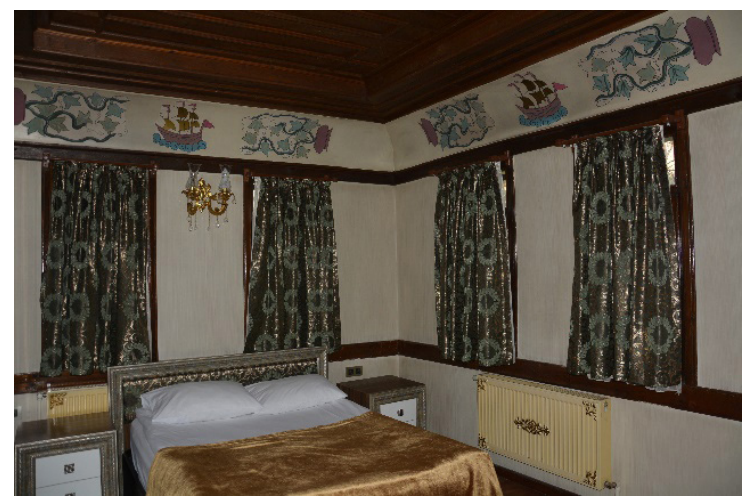

Fotoğraf 36. Çelik Palas Hotel İç Mekân Detayı (kişisel arşiv)

Sit alanında inşa edilen bir diğer dikkat çekici yapı ise mimar Çetin Artalya tarafından 2014-2016 yılları arasında yapılan Hilton Garden Inn'dir. Hilton'un sit alanında inşa edilmesi yapının cephesinde geleneksel Safranbolu dokusuna bağlı kalmayı zorunlu kılmıştır. Bunun sonucunda pencere düzenlemeleri, çıkmalar, katlar arasındaki ahşap şeritler ile çatı düzenlemesi geleneksel dokuya atıf içerir. Ancak yapının iç mekânında geleneksel dokuya herhangi bir öykünme yoktur.

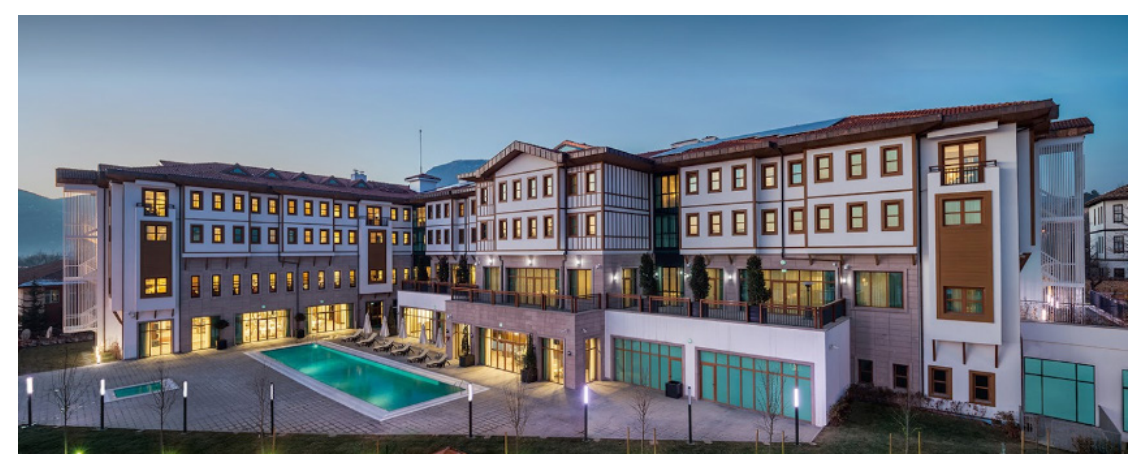

Fotoğraf 37. Hilton Garden Inn ${ }^{35}$

Çelik Palas’a yakın bir noktada yer alan ancak sit alanında olmayan Zalifre Oteli ise iç mekânında geleneksel dokuya yer verilmemiş olsa da diş cephede özellikle pencere düzenlemeleri, çıkmalar, katlar arasındaki ahşap şeritler, çatı düzenlemeleri ve renk dokusu ile geleneksel Safranbolu evlerine oldukça güçlü öykünme barındırır. 


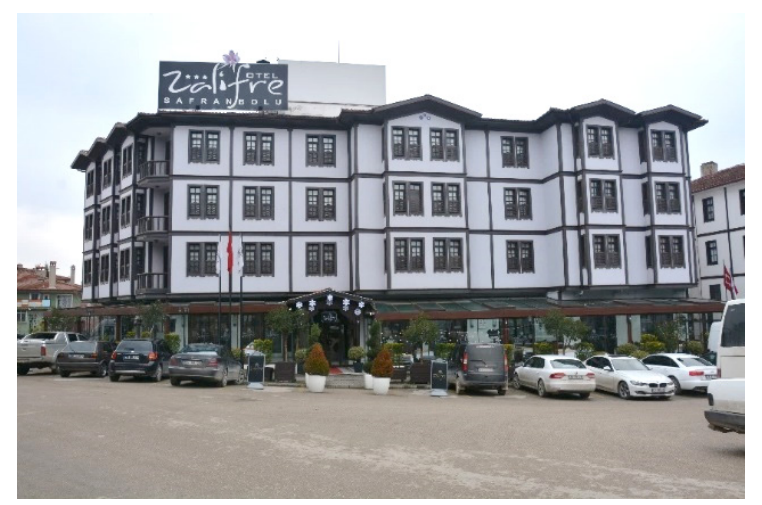

Fotoğraf 38. Zalifre Otel (kişisel arşiv)

Meydan ve Peyzaj Düzenlemelerinde Yaptırılan Geleneksel Etkideki Dekoratif Ögeler

Kentlerin tarihi kimliklerinin korunması için çoğunlukla şehrin çeşitli yerlerinde kenti temsil edecek anıtlar yapıldığı görülmektedir. Bu anıtlar ülkenin önemli şahsiyetlerini, önemli olaylarını, kentin coğrafi ve ekonomik özellikleri ile tarihi kimliğini yansıtan ögelere sahip olabilmektedir.

Tarihi Safranbolu kentinin yeni yerleşim yerlerinde belediye tarafından gerçekleştirilen bazı peyzaj düzenlemeleri kapsamında refüj ve meydanlara yapılan dekoratif nitelikteki simgelerde geleneksel mimariye atıflar söz konusudur.

Safranbolu ile Emek Mahallesi yol ayrımındaki kavşağın refüj düzenlemesine dekoratif amaçla yerleştirilen geleneksel Safranbolu evinin minyatür modeli buna örnektir.

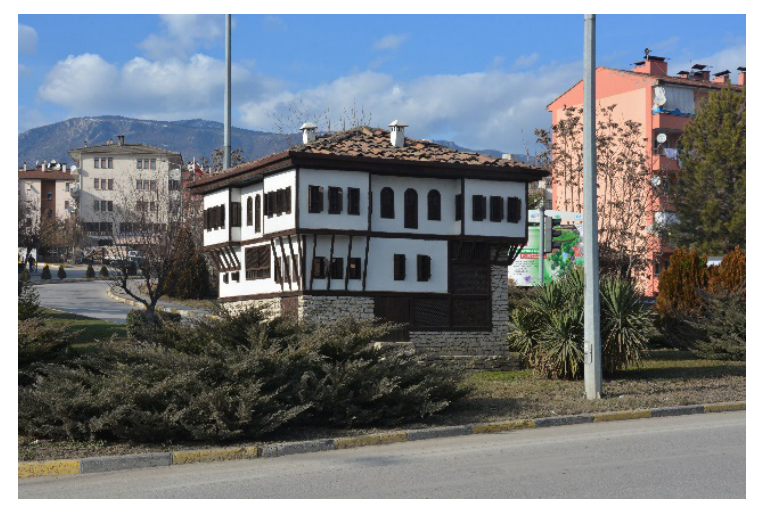

Fotoğraf 39. Minyatür Ev Modeli (kişisel arşiv)

Geleneksel Safranbolu dokusuna atıf içeren diğer bir işlevsel yapı da kent dokusunun meydan alanını oluşturan refüjlerinden birine yerleştirilen kuş evidir. Kuş evi, yüksekçe madeni bir direk üzerine konumlandırılmış ve geleneksel Safranbolu evinin bir modelidir. 


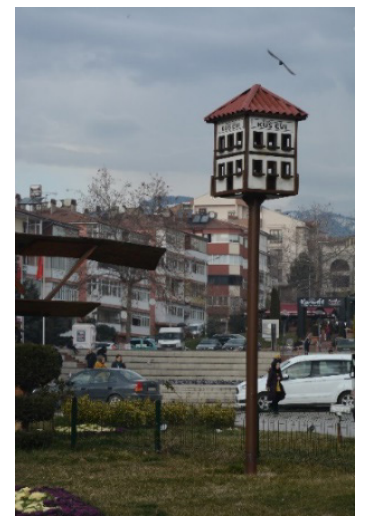

Fotoğraf 40. Kuş Evi (kişisel arşiv)

Yine Safranbolu Otogarı önünde inşa edilen yaya üst geçidindeki asansör kulelerinin üst bölümü, Safranbolu’nun 1794-1797 tarihli saat kulesine atfen geleneksel anlayışta dekoratiftir.

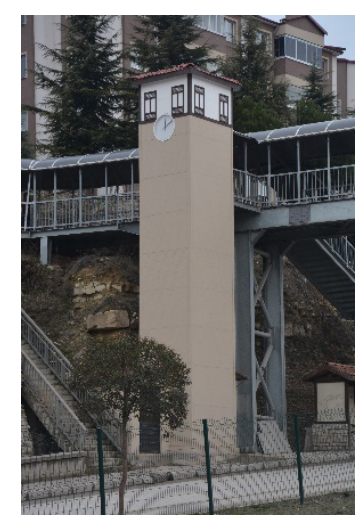

Fotoğraf 41. Yaya Üst Geçidi Asansör Dekoru (kişisel arşiv)

Belediyenin izniyle hem dekoratif hem de işlevsel olarak inşa edilen Meydan Çeşmesi (2014) de Osmanlı Dönemi Meydan Çeşmeleri’ne öykünme içerir. Çeşme, ayrıca yöresel mimari ögeleri de barındırır.

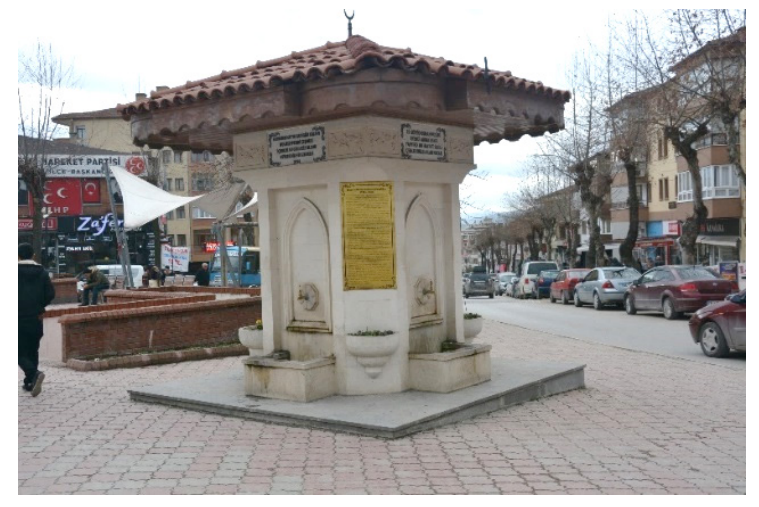

Fotoğraf 42. Meydan Çeşmesi (kişisel arşiv) 
Bu meydan çeşmesi dört cephesinde de geleneksel Osmanlı çeşme form ve biçimine sahiptir ancak çatı konstrüksiyonu geleneksel Safranbolu evlerinin çatı özelliklerini barındırır. Bu şekliyle ulusal bir mimari yapı olan meydan çeşmesi yöresel mimari karakterle bütünleştirilmiştir.

\section{Sonuç}

Konumu, iklim koşulları ve coğrafi yapısıyla ülkemiz; tarih boyunca önemli bir yerleşim yeri olmuş ve bunun sonucunda kültürel açıdan oldukça zengin bir yapı ortaya çıkmıştır. Safranbolu da konumu itibariyle bu ilgiden payını alan ve günümüzde de bunu devam ettiren bir yerleşim yeridir.

1994 yılında UNESCO’nun aldığı kararla Dünya Kültür Mirası Listesi’ne giren Safranbolu, uluslararası düzeyde bir turizm şehrine dönüşmüştür. Bunun etkisiyle kentte yeni inşa edilen birçok yapıda geleneksel mimari dokuya bağlılık öne çıkmıştır. 2000'li y1llardan sonra bu durum daha da görünür olmuştur. Yeni inşa edilen siteler ve konaklama tesislerindeki geleneksel dokuya öykünme çabaları, modern dönemde inşa edilmiş seçmeci anlayıştaki geleneksel ögelerin mimariye taşındığı yapı tiplerini ortaya çıkarmıştır. Bu yapıların gerçekleştirilme amacı ile geleneksel dokuya bağlı kalma arasında önemli ilişkiler söz konusudur. Örneğin özellikle ticari amaçla inşa edilen yapılarda hem turistler için otantik bir ortam oluşturma hem de gündelik ihtiyaçlara cevap verme amacıyla dış mimaride geleneksel ögelere öykünülmüş ancak iç mekânda ekonomik maliyetten dolayı bundan imtina edilmiştir.

Bağımsız tek bir ailenin kaldığı konaklar, site olarak inşa ettirilen yapılardan daha fazla geleneksel dokuya öykünme içerir. Bu evlerde ev sahibinin hassasiyeti ve geleneğe bağlı kalma arzusu yapının özellikle iç mekânındaki geleneksel dokunun devam edip etmemesine doğrudan etki etmiştir. Hem yapının sit alanı içinde olması hem de ev sahiplerinin geleneksel dokuya bağlı kalma amacı gütmesi sonucu bazı yapıların cephesinde ve iç mekânında geleneksel dokunun etkisi oldukça yüksektir. Bunun yanı sıra cephede geleneksel dokuya bağlı kalınmakla birlikte iç mekânlarda geleneksel dokuya bağlılık hususunda istekli olunmadığını gösteren örnekler de mevcuttur. Özellikle de sit alanı içinde geçmiş tarihlerde gerçekleştirilen hem özel teşebbüslere ait yapılarda hem de kamu yapılarında geleneksel dokuya bağlı kalma çabasının göstermelik bir uygulamanın ötesine geçmediği görülmektedir. Ticari amaçla tarihi doku içinde inşasına izin verilen bazı konaklarda tarihi dokuyu koruma kaygısının göz ardı edilmesi sonucu geleneksel dokuya bağlı uygulamaların oldukça yüzeysel kalabildiği görülmektedir. Bu duruma müsaade edilmesinin kısa vadede olumsuz etkilerinden ziyade uzun vadede ortaya çıkaracağı sorunlar daha fazla irdelenmelidir. Çünkü geleneksel doku, ticari çıkarlar gözetilerek göz ardı edildiğinde ilerleyen yıllarda geleneksel dokunun mimari özelliklerinin bu yeni yapılarda aynen sürdürüldüğü yanılgısı oluşabilecektir.

Benzer sorunları kamu yapılarında da görmek mümkündür. Özellikle 1990’lı yıllardan önce sit alanı içine inşa edilen kamu niteliğindeki kurumlarda (okul, idari binalar) geleneksel dokuya öykünme neredeyse hiç umursanmamıştır. Buna, günümüzde 
Kalealtı İlkokul ve Ortaokulu olarak hizmet veren bina dramatik bir örnektir. Okul, sit alanı ilan edilen bölgede yer almasından ötürü yalnızca cepheleri göstermelik bir mimari uygulamanın ötesine geçemeyen geleneksel mimariye öykünmeler içerir.

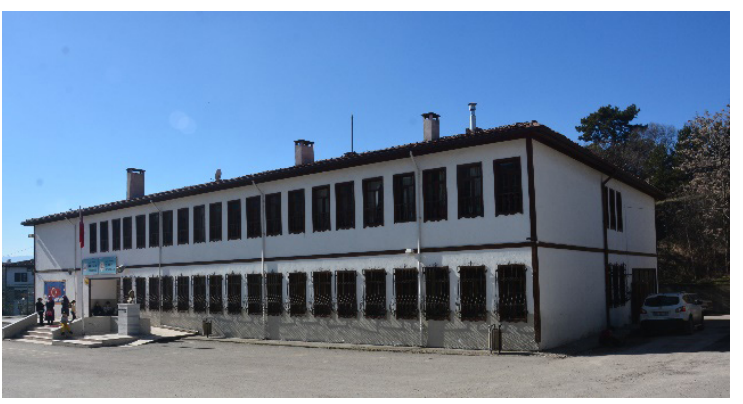

\section{Fotoğraf 43. Kalealtı İlkokul ve Ortaokulu (kişisel arşiv)}

2000 'li yıllardan sonra ilk kez inşa edilecek yapılarda geleneksel Safranbolu dokusuna bağlı kalma duyarlılığı artmış olsa da ekonomik, siyasi vb. çıkarlar gözetilerek göstermelik uygulamaların yapılması ihtimali halen devam etmektedir. Toplumda kültürel varlıkları koruma ve bunu geleceğe taşıma hususundaki duyarlılığı kişisel çıkarlardan daha üstün tutacak nitelikteki nesiller yetiştirilmesi için eğitimde tarihi ve kültürel mirasın korunması hususundaki hassasiyetin öne çıkarılması zorunluluktur.

Safranbolu’da özellikle kentsel sit alanı olarak belirlenen Eski Çarşı ve Kıranköy tarihi şehir dokusu barındırdığından dolayı, bu bölgelerde ilk kez yapılan ya da yenilenen evlerin cephe ve iç mekanlarında geleneksel dokuya olduğu gibi bağlı kalınması daha uygundur. Kentsel sit alanı olarak belirlenen bölge dışındaki sit alanlarında modern yapı tasarımlarının geleneksel dokuya öykünülerek yorumlanması mümkündür. Ancak, kentin sit alanı olarak kabul edilmeyen yeni yerleşim bölgelerinde geleneksel mimariyi olduğu gibi kopya etmek sürdürülebilirlik açısından mimari bir zorunluluk olmamalıdır. Böylece günümüzdeki yaşam koşulları ve mimari arasındaki ilişki ile kentin tarihsel dokusuna öykünülmüş uyumlu bir birlikteliğin sağlanması mimarlık tarihi açısından tutarlı bir süreç yaşanmasının da önünü açacaktır.

Safranbolu’nun ülkemiz sınırları içinde Dünya Kültür Mirası olarak kabul edilen tek kentsel sit alanı olması, Safranbolu'nun modern yapı uygulamalarında geleneksel yapıya öykünme ya da onu temsil edebilecek uygulamalar ile modern ve geleneksel mimari arasında uyum yakalama çabalarını görünür kılmıştır. Ülkemizde tarihi kent dokusunun korunduğu yerleşim yeri yalnızca Safranbolu değildir. Dünya Kültür Mirası Listesi'ne dahil edilmemiş olsalar da kent ölçeğinde Safranbolu'ya benzer başka yerleşim yerleri mevcuttur. Bu özellikteki yerleşim yerleri çoğunlukla geleneksel etkide yapılmış tekil örnek yapılar içerse de bazılarında kentsel düzeyde koruma alanlarının oluşturulduğu bölgeler mevcuttur. Bartın Amasra, Amasya, Bursa, İstanbul, Mardin, Ankara Beypazarı, Kastamonu, Kars, Erzurum, Ayvalık, Havran, Harran, Van, Alaçatı, Fethiye ve daha pek çok yerleşim yeri bunlar arasında sayılabilir.

Kentlerin tarihi kimliği ve mimari dokusunun son yarım yüzyılda peyder pey artan ilgiden ötürü koruma altına alınması ihtiyacı kültür turizmi açısından önem kazan- 
mıştır. Tarihi ve kültürel dokusu öne çıkan bu kentlerde çeşitli ihtiyaçlara binaen inşa edilecek yapılarda geleneksel dokunun göz ardı edilmemesi, günümüz mimari anlayışına uyarlanarak sürdürülmesi önemlidir. Safranbolu’nun kent ölçeğinde koruma altına alınması ve tarihi dokusunu koruyarak yeni kent dokusu ile gelişim açısından uyum göstermesi Safranbolu'yu diğer kentlerden ayırt eden en önemli unsurdur. Örneğin kent ölçeğinde tarihi bakımından Safranbolu'ya benzerlik gösteren Mardin'de geleneksel mimari karakterin yeni kent dokusuna, Mardin Artuklu Üniversitesi Rektörlük Binası gibi tekil örnek oluşturabilecek yapılar dışında taşınmadığı görülmektedir. Benzer şekilde Kars ve Erzurum kentlerindeki tarihi yapılar son yıllarda koruma altına alınmış olmasına karşın, bu kentlerde yeni inşa edilen yapılarda tarihi şehir dokusuna bağlı kalma hususunda Safranbolu'ya nazaran oldukça geride kalınmıştır. Ankara ve Kastamonu kentlerinin bazı bölgelerinde ise Safranbolu gibi geleneksel mimari ile modern mimarinin bir arada kullanıldığı yapılar ve sokak dokuları görülmektedir. Bunların yanı sıra günümüzde Karabük, Safranbolu ilçesi ile neredeyse tamamen birleşmiş ${ }^{36}$ olmasına rağmen İl Emniyet Müdürlüğü ve Milli Eğitim Müdürlüğü binalarının cepheleri dışında geleneksel tarihi Safranbolu evlerine öykünme görülmez. Modern Safranbolu’yu diğer tarihi benzer dokulara sahip -Kastamonu, Amasya dışında-yerleşim yerlerinden ayıran temel unsur geleneksel etkinin birkaç yapıyla sınırlı kalmayarak modern sokak dokusunu oluşturacak düzeyde ortaya çıkmasıdır.

Tarihi kimliğinin Safranbolu kentine sağladığı ekonomik ve sosyal imkânlar kenti, ülkemizin en gözde ilçeleri arasına sokmuştur. Kentin turizm potansiyeli ile birlikte ticari açıdan gelişmesi ve toplumsal dokunun çeşitlenmesiyle ortaya çıkan olumlu durum kentteki insanların bu duruma uygun davranışlar geliştirmesi sonucunu doğurmuştur. Böylece tarihi dokuya verilen önem toplum nezdinde giderek artmıştır.

Safranbolu'da geleneksel mimariye öykünülerek yapılan konutların tüm konutlar içindeki payı 2000'li yıllardan sonraki gelişmelere rağmen nicel olarak oldukça azdır. Kentte geleneksel dokuya öykünme özellikle Eski Çarşı, Kıranköy, Bağlarbaşı Mahallesi ve Aşağıtokatlı Mahallesi’ne yakın ya da o bölgelerle etkileşimli noktalarda yer alan mahallelerde yoğunlaşmıştır. Kentin tarihi dokusuna hâkim ya da yakın noktalarındaki yerleşim yerlerinde geleneksel dokuya öykünmenin diğer bölgelere nazaran belirgin bir şekilde yoğunlaştığ 1 , bu yöndeki eğilimin de artarak devam ettiği görülmektedir.

\section{Kaynakça}

Anonim. (Abad Proje Proje Yapı Turizm Sağlık Enerji San. ve Tic. A.Ş.) Safranbolu (Karabük) (Korumanın Başkenti) Koruma Amaçlı Revizyon + İlave Nazım ve Uygulama İmar Planı Araştırma Raporu. 2010.

36 İller Bankası planlama sürecini 1968 yılında “Karabük- Safranbolu Analitik Etütler ve Teklif Projeler” başlığı altında yayımlanan kitaptan aktaran; Suat Çabuk, Kemal Demir ve Ercan Gökyer, Cumhuriyet'in Yeni Kenti Karabük'ün 1937 - 1988 Dönemi Mekânsal Gelişimi ve Şehir Planları, Karabük Üniversitesi, Sosyal Bilimler Enstitüsü Dergisi, II (2016), s.31,32. 
Aktüre, Sevgi, Şenyapılı, Tansı. Safranbolu’da Mekânsal Yapının Gösterdiği Nitelikler. O.D.T.Ü. Mimarlık Fakültesi Dergisi. 2/I (1976): 61-96.

Arşiv Belgelerinde Karabük. Haz., Recep Karacakaya, İsmail Yücedağ ve Nazım Yılmaz. İstanbul: Safranbolu Belediyesi Kültür Yayınları, 2013.

Bayazıt, Nigan. Safranbolu Evlerinin Plan Tipolojisi ve Kullanıcı İhtiyaçları Hiyerarşisi. Tasarım-Kuram, 17 (2014): 1-15.

Bayazıt, Nigan. Safranbolu Geleneksel Konutları ve Toplumsal Değişme. İstanbul: Safranbolu Belediyesi Safranbolu Araştırmalar Merkezi Kültür Yayını, 2014.

Bozkurt, Gülçin Selvinaz. 19. yy'da Osmanlı Konut Mimarisinde İç Mekan Kurgusunun Safranbolu Evleri Örneğinde İrdelenmesi. Journal of the Faculty of Forestry, Istanbul University. 62/II (2013): 37-70.

Cumhurbaşkanlığı Seçimleri ve Genel Seçimler Seçim Beyannamesi. Haz., Ak Parti Genel Merkezi, Ankara, 2018. Erişim 10 Ocak, 2019.

http://image.yenisafak.com/resim/Beyanname23May\%C4\%B1s18_icSayfalar.pdf.

Çabuk, Suat, Demir, Kemal ve Gökyer, Ercan. Cumhuriyet’in Yeni Kenti Karabük'ün 1937 - 1988 Dönemi Mekânsal Gelişimi ve Şehir Planları. Karabük Üniversitesi Sosyal Bilimler Enstitüsü Dergisi. II (2016): 20-39.

Eldem, Hakkı Sedat. Türk Evi. Ankara: Türkiye Anıt ve Çevre, Turizm Değerlerini Koruma Vakf1, 1984.

Gezer, Hale. Geleneksel Safranbolu Evlerinin Sürdürülebilirlik Açısından Değerlendirilmesi. İstanbul Ticaret Üniversitesi Fen Bilimleri Dergisi. XXIII (2013): 13-31.

Gökoğlu, Ahmet. Paphlagonia-Paphlagonia, Kastamonu, Sinop, Çankırı, Safranbolu, Bartın, Bolu, Gerede, Mudurnu, İskilip, Bafra, Alaçam ve Civarı Gayrimenkul Eski Eserleri ve Arkeolojisi. Kastamonu: Doğrusöz Matbaası, I, 1952.

Günay, Reha. Geleneksel Safranbolu Evleri ve Oluşumu. Ankara: Kültür Bakanlı̆̆ı Yayınları, 1981.

Günay, Reha. Safranbolu Houses. İstanbul: Yapı Yayın, 2005.

Günay, Reha. Türk Ev Geleneği ve Safranbolu Evleri. İstanbul: YEM, 1998.

Hacısalihoğlu, Yaşar İlhan. Geleneksel Türk Şehri: Safranbolu. Türk Coğrafya Dergisi. XXX (1995): 409-434.

Kara, Şeref, Uysal, Burhanettin ve Sümerkan, Reşat M. “Tarihi Safranbolu Evlerinin İskelet Yapısı”. Haz. Özköse, Aysun. Anadolu’nun Ahşap Evleri, Ankara: Kültür Bakanlığı Yayınları, 2001.

Karacakaya, Recep, Yücedağ, İsmail ve Kılavuz, Nuri Bülent. Safranbolu Kitabeleri. İstanbul: Safranbolu Belediyesi Kültür Yayınları, 2013. 
Koçan, Nurhan. Safranbolu'da Zaman ve Mekân. İstanbul: Safranbolu Belediyesi Kültür Yayınları, 2012.

Merçil, Erdoğan. Selçuklular Devrinde Karadeniz ve Safranbolu. I. Ulusal Tarih İçinde Safranbolu Sempozyumu 4-6 Mayıs 1999, Karabük: Türk Tarih Kurumu Basımevi, 2003, s.1-6.

Nartkaya, Esra, Tektaş, Elif. Erken Cumhuriyet Dönemi Safranbolu Konut Yapılarında Kimlik Arayışı. Dicle Üniversitesi I. Uluslararası Mimarlık Sempozyumu (Dicle University I. International Architecture Symposium), Diyarbakır: 2018.

Nigan, Bayazıt. Safranbolu Evlerinin Plan Tipolojisi ve Kullanıcı İhtiyaçları Hiyerarşisi. Tasarım-Kuram, 14 (2014): 1-15.

Nigan, Bayazit. Safranbolu Geleneksel Konutları ve Toplumsal Değişme. İstanbul: Safranbolu Belediyesi Safranbolu Araştırmalar Merkezi Kültür Yayını, 2014.

Özköse, Aysun. "Safranbolu’da Yorgun Ahşap Yapı Kültürü". Haz. Özköse, Aysun. Anadolu’nun Ahşap Evleri, Ankara: Kültür Bakanlığı Yayınları, 2001.

Safranbolu'da Kültür ve Medeniyet İzleri Araştırması. Haz., Hür Mahmut Yücer. Proje Yönet., Sami Şener. Karabük: Safranbolu Belediyesi Kültür Yayınları, 2014.

Safranbolu Şer'iyye Sicili, 2116 Numarah Defter. Haz., Recep Karacakaya, İsmail Yücedağ ve Nazım Yılmaz. İstanbul: Safranbolu Belediyesi Kültür Yayınları, 2013.

Türkiye’nin Dünya Miras Alanları, Koruma ve Yönetimde Güncel Durum. UNESCO Türkiye Milli Komisyonu Somut Kültürel Miras İhtisas Komitesi, Haz., Ayşe Bayvas. Ankara: UNESCO, 2009.

Yetiş, Rüveyda, Turcan, Yüksel ve Dinçer, Emre Ahmet. Safranbolu Kent Formunun Tarihsel Serüveni ve Morfolojik İncelemesi. "DeğişKent” Değişen Kent, Mekân ve Biçim Türkiye Kentsel Morfoloji Araştırma Ağı II. Kentsel Morfoloji Sempozyumu. İstanbul: 2018, s. 495-515.

Yılmaz, Nazım. 'Arşiv Belgeleri Ișı̆ğında Karabük Şehri ve Karabük Demir Çelik Fabrikası Tarihi Süreci'. Kuruluşundan Bugüne Karabük ve Demir Çelik Sempozyumu. 2-3 Nisan 2010, Ankara: TBMM Basım Evi, 2010, s. 1-16.

Yöresel Mimarisinin Adalet Saraylarındaki İzleri. haz., Gökçe Aras, Erişim 12 Ocak, 2019. http://v3.arkitera.com/h13461-yoresel-mimarinin-adalet-saraylarindakiizleri.htmlArkitekt. 


\title{
Today's Safranbolu Civil Architecture in Respect to Imitation of Traditional Architecture
}

BÜLENT ORAL

\begin{abstract}
In this study, effect of traditional Safranbolu architecture's style on new constructions built in modern period via example structures are aimed to be presented. Thus, the aspects affect today's art understanding, factors reveal these aspects and effect of all these to modern art will be understandable. Especially after 2000, efforts of imitation to traditional patterns in newly constructed sites and resorts created new structural types of acchitecture and eclectic conceptions. Adheison to tradition in structures are dense on the front but it was not reflected indoors to this extend. Imitation to traditional structure in city is dense in Eski Çarşı, Kıranköy and Bağlarbaşı districts and abouts and the tendancy to this matter seems to increase. Historical Safranbolu city is the only urban protected area accepted as World Cultural Heritage by the UNESCO within the borders of our country. This situation made visible the orientation efforts between modern and traditional architecture.
\end{abstract}

Keywords: Safranbolu, Architecture, Modern, Traditional, Civil. 